\title{
Gemstones in the ERa of the Taj Mahal AND THE Mughals
}

Dona Mary Dirlam, Chris L. Rogers, and Robert Weldon

The Taj Mahal evokes an image of a monumental building and reflecting pool—its classic view. But the Taj Mahal complex is much more than that. It is actually a series of beautiful buildings and gardens in Agra, India, built in the seventeenth century in loving memory of Mumtaz Mahal. This name, given by the Mughal emperor Shah Jahan to one of his brides, means "Chosen One of the Palace." Famed for its architectural magnificence, the landmark holds additional significance for the gemologist. Upon closer investigation, one is impressed with the intricacies of the inlay of numerous gems to create thousands of designs throughout the buildings on the grounds. This article sheds light on the gems used in decorating the Taj Mahal and in the extraordinary jewelry collected by Shah Jahan and other Mughals. These gems often took intricate trade routes to Agra, which are also discussed, along with the craft used to create the inlays and the efforts undertaken to preserve this Wonder of the World.

$\mathrm{T}$ he magnificent Taj Mahal is a large complex of buildings and gardens in the city of Agra, located in the northern Indian state of Uttar Pradesh (figure 1). The Yamuna (or Jumna) River flows in a wide arc around the rear of the majestic site (figure 2). Recognized as one of the most beautiful structural compositions in the world, it was designated as a UNESCO World Heritage site in 1983. Visitors are amazed by its breathtaking beauty. Its exquisite domed white marble mausoleum, situated within four gardens with raised walkways and reflecting pools, is one of the most astonishing architectural marvels.

Viewed from the south, it is startling to realize that the Taj Mahal is not set in the serene countryside, as photos suggest, but rather in a largely impoverished city with a population of nearly two million (figure 3). The city of Agra has expanded around the complex. Walking around the grounds and taking a closer look at the buildings, one marvels at the elaborate decorative inlay that includes ornamental gem materials as well as fine gems. This stonework is generally referred to as pietra dura ("hard stone" in Italian) and known as parchin kari in India.

See end of article for About the Authors and Acknowledgments.

Gems \& Gemologr, Vol. 55, No. 3, pp. 294-319,

http://dx.doi.org/10.5741/GEMS.55.3.294

(C) 2019 Gemological Institute of America
Emperor Shah Jahan (1592-1666), who ruled from 1628 to 1658 , built the Taj Mahal for one of his wives, Mumtaz Mahal. Construction began shortly after her death. It eventually took more than 1,000 elephants and 20,000 craftsmen from all

\section{In Brief}

- The Mughal era, from the early sixteenth to midnineteenth century, ushered in a time of unparalleled patronage of the arts, gem collecting, and architecture in India.

- The inspiration for the Taj Mahal, which took more than two decades to complete, was love.

- Trade during the Mughal era spread ideas, products, and culture across land and sea on a global scale.

- A signature design element of the Taj Mahal is the exquisite parchin kari hard stone inlay that incorporated gem materials from various sources.

over Asia to build (Nath, 1985). Begun in 1632, the entire complex was not completed until 1653 (Sarkar, 1920; "The Taj Mahal," n.d.). In 2007, it was chosen as one of the New Seven Wonders of the World.

In this article, we will examine the story behind the detailed features of the gem inlay work as well as the history and architecture of the Taj Mahal, 


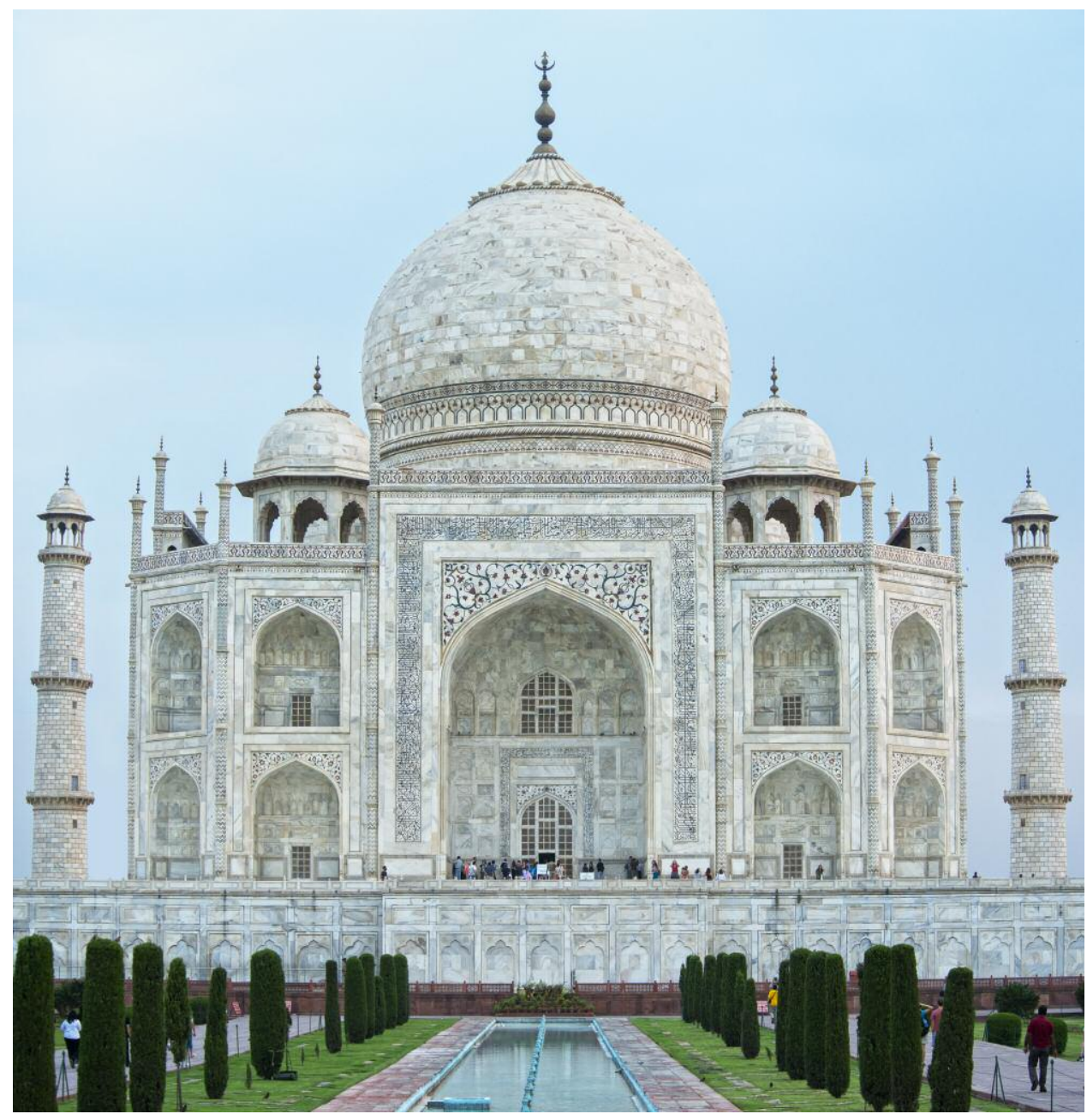

Figure 1. The grandeur of the Taj Mahal and its intricate stone inlays immediately greets the visitor upon entering the complex in Agra, India. Photo by Robert Weldon/GIA

which represents the artistic height of the Mughal dynasty. Through famous portraits, we will get a glimpse of the types of jewels and gems acquired by

Figure 2. The Taj Mahal complex is best viewed from a distance, in this case from the Yamuna River. Photo by Robert Weldon/GIA.

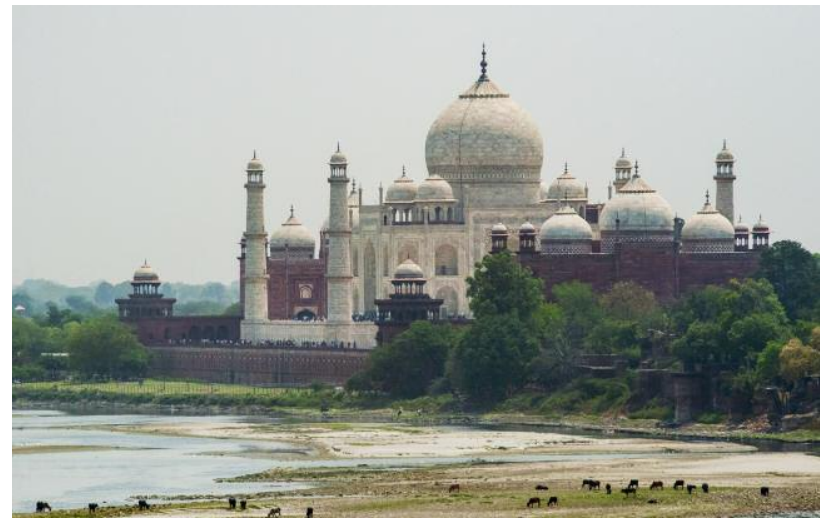

Shah Jahan. We will also see gems and jewels that illustrate gem connoisseurship of the Mughal era at its pinnacle (Jaffer, 2013).

Figure 3. The city of Agra has grown along the edges of the Taj Mahal, which presents challenges to the integrity and long-term survival of the architectural marvel. Photo by Robert Weldon/GIA.

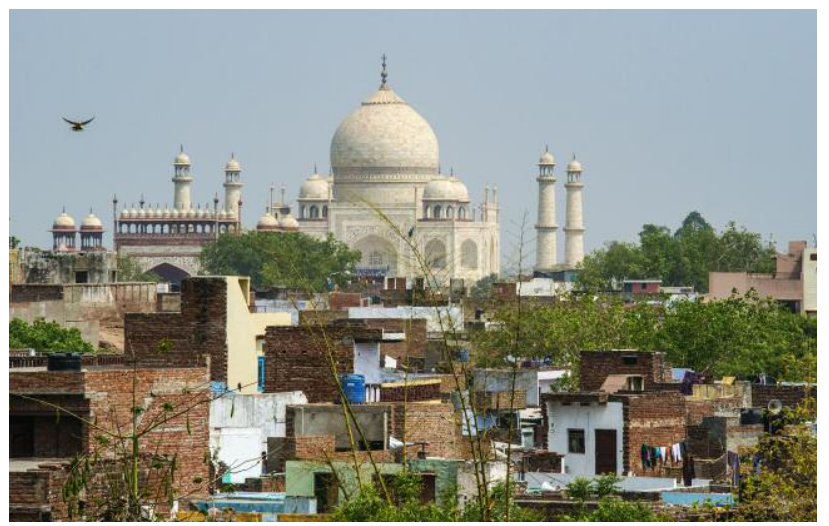




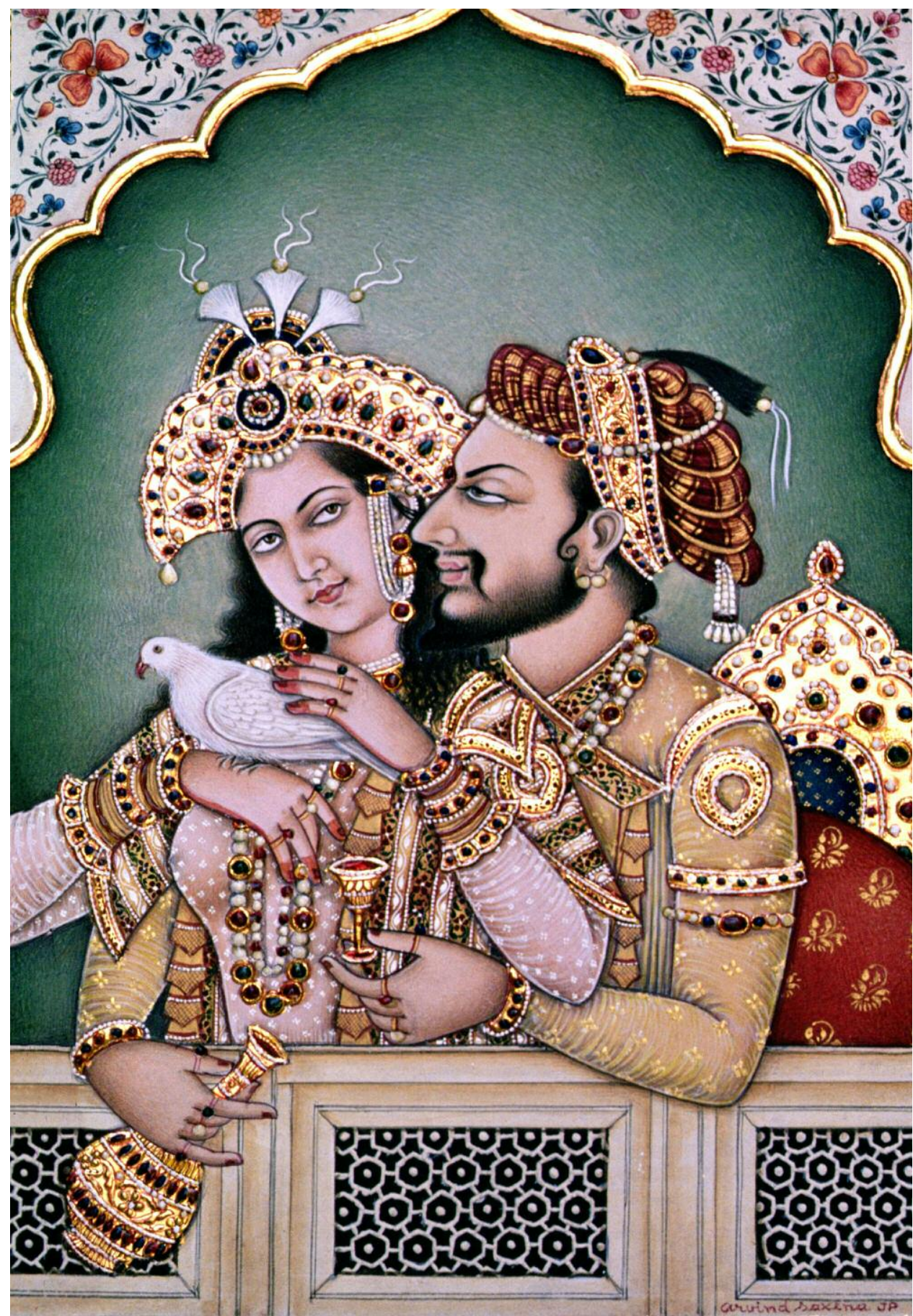

Figure 4. Shah Jahan (1592-1666) and his wife Ariumand Banu Begum, who became known as Mumtaz Mahal, appear in this painting from the Indian School. From a private collection, courtesy of Dinodia/Bridgeman Images.

\section{INSPIRATION FOR THE TAJ MAHAL}

Called "a teardrop on the cheek of time" by Indian poet Rabindranath Tagore (Nath, 1985), the marvel of architecture and art known as the Taj Mahal was inspired by love-specifically, the devotion for one woman, Arjumand Banu Begum. Shah Jahan, a son of Jahangir, met her in 1607 when she was just 15 years old. He asked to marry her the next day, but ro- mantic marriages were unheard of, even for a prince; they were traditionally arranged. It would be another five years before they could marry.

After they married, Arjumand Banu Begum became known as Mumtaz Mahal, or "Chosen One of the Palace." Shah Jahan's two other marriages were secured for political reasons. Although he bore one child each with his other wives, they were no com- 

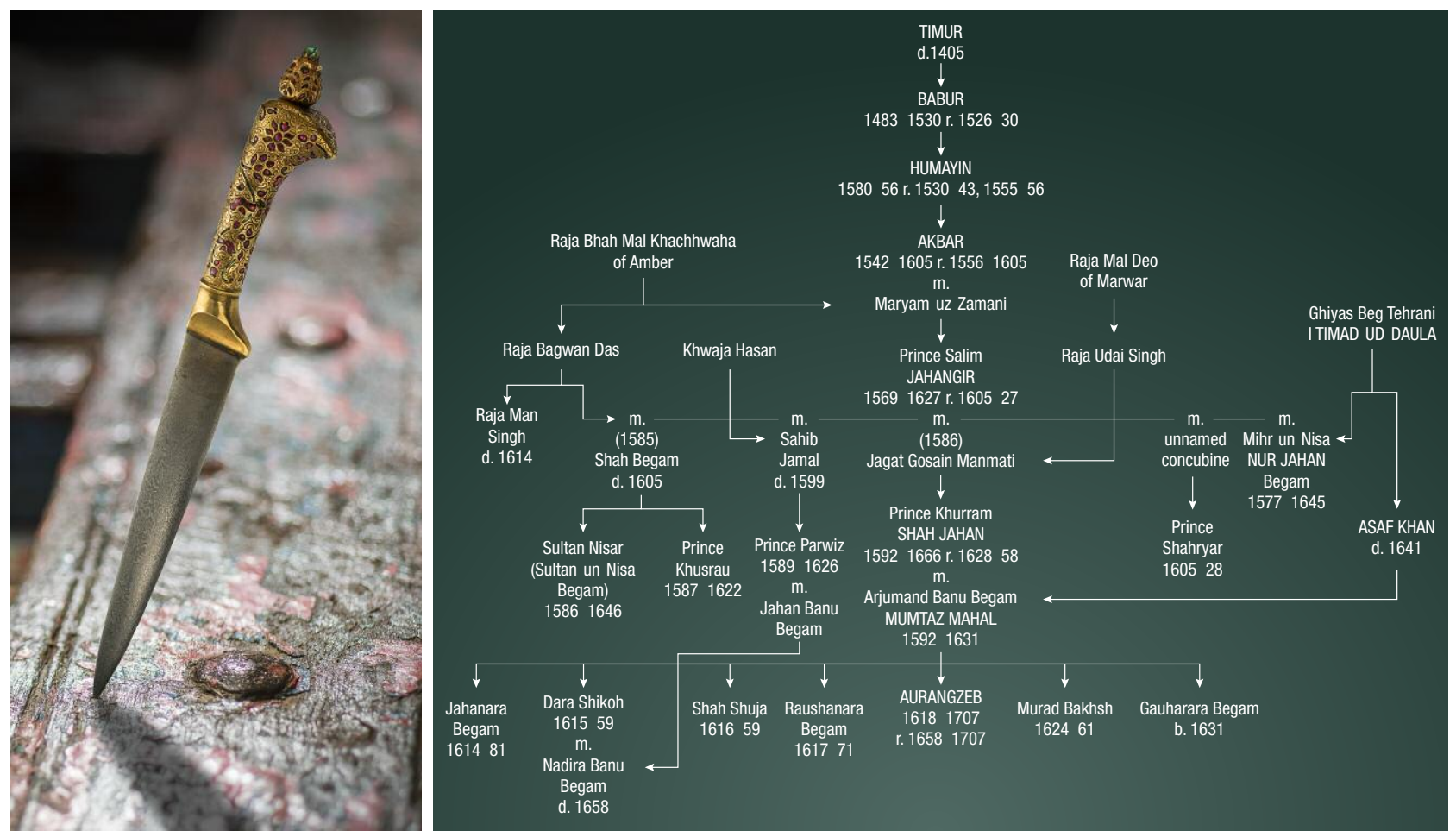

Figure 5. Left: This seventeenth-century ceremonial knife from Hyderabad contains emerald, ruby (including some recently replaced treated ruby), and Damascus steel with a $23 \mathrm{~K}$ engraved gold handle. Photo by Robert Weldon/GIA. Right: Genealogy of the Mughal dynasty, reproduced with permission of Ebba Koch.

petition for his affections (figure 4). Mumtaz gave birth to fourteen children from their marriage, though only seven survived.

Mumtaz's reign as queen was short-lived. Three years later, she died moments after the birth of their fourteenth child. Early accounts say that she whispered two final requests. One was that he not remarry. The second was to build a monument to resemble paradise on earth, just as she had dreamed of the night before her death (Nath, 1985).

Mumtaz was temporarily buried in the garden of Zainabad. Almost immediately, Shah Jahan began work on what would emerge as one of the greatest memorials ever constructed. He took inspiration from a verse from the imperial goldsmith and poet Bibadal Khan: "May the abode of Mumtaz Mahal be Paradise" (Koch, 2006). He chose a site on the banks of the Yamuna River at Agra. Shah Jahan called the mausoleum a "monument of sorrow" (Nath, 1985).

Shah Jahan's Place in the Mughal Lineage. Babur (1483-1530), a Central Asian prince who went to India in search of wealth and conquest, became the founder of the Mughal Empire in 1526 (see the genealogy chart in figure 5). Babur distributed the spoils from his wars among the nobles whose soldiers fought, following the tradition of Timur or Tamerlane (r. 1370-1405) of the Central Asian Dynasty. Babur and his Mughal successors embraced their Timurid ancestry through subjugation to legitimize and solidify their rule. This is apparent in the succession leading to Shah Jahan's rule. In 1628, Shah Jahan succeeded his father. His eldest brother failed to take the throne, and his other brother died under mysterious circumstances. Shah Jahan had other potential successors killed (Delmerick, 1883). He became the new emperor through this process of elimination, earning him the title "King of the World" (Koch, 2006). Shah Jahan would encounter similar familial struggles for power in his later years. After a serious illness, he was deposed and imprisoned by his own son, Aurangzeb, in 1658. Nonetheless, the rulers saw the importance of documenting their rule, which they did by having the names of their ancestors (and the current ruler) inscribed on the most treasured of the gems they obtained through trade.

As Jaffer (2013) points out, "India was a land of fabled wealth that had lured both conquerors and merchants from around the globe since antiquity." The Indian subcontinent was known for its gems and jewelry, a place where aspirations for owning them became a part of daily life for people of all classes and religions. 


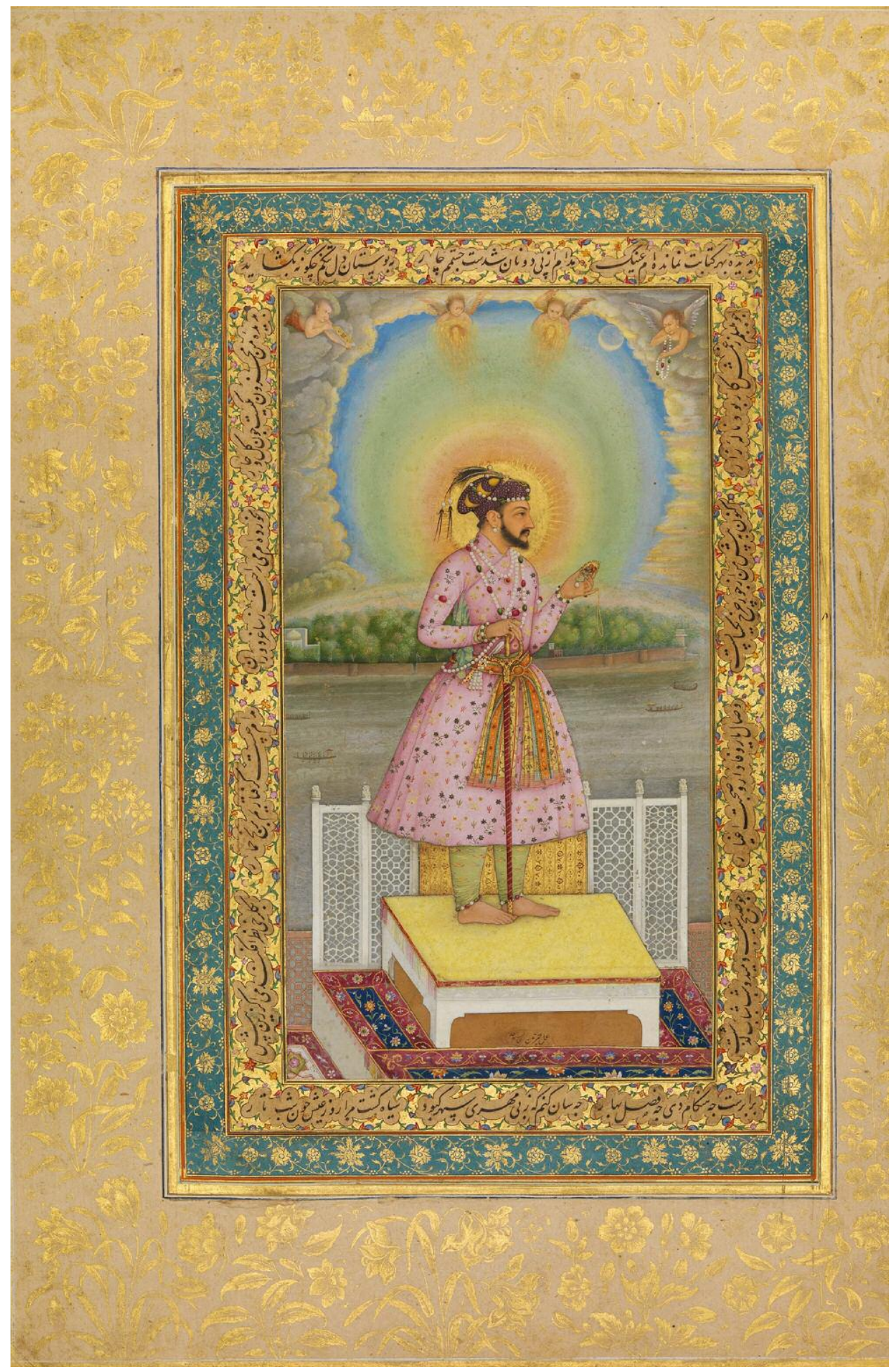

Figure 6. This portrait by Chitarman, his earliest dated painting, shows Shah Jahan exquisitely dressed and richly adorned with jewels. His imperial halo and the hovering angels are borrowed from European art. Courtesy of the Metropolitan Museum of Art, public domain.

To the Mughals, gems, jewelry, and jeweled objects were more than just beautiful treasures: They were symbols of power. Mughal expansion was an effort to acquire more territory and more of these treasures. The Mughals had competition in their expansion from two other great regional Muslim empires, the Ottomans and the Persian Safavids.

It is remarkable that we have such detailed information and resources about this period. Some of the information comes from court records, inventories by 
jewelry and gem curators, writings by the Mughal rulers themselves, and foreign travelers such as Sir Thomas Roe and Jean-Baptiste Tavernier. Court paintings also provide intricate detail about the style and variety of gems treasured by the Mughal leaders.

The Mughals' Support for the Arts. With the ascension to the throne of Jahangir, Shah Jahan's father, the Mughals' patronage of artisans began to flourish, especially when he married a supporter of the arts, Nur Jahan (Latif, 1982). Jahangir was known to wear gemstones and pearls with extravagance. In 1619, Flemish diamond dealer and noted chronicler Jacques de Coutre described the emperor as "looking like an idol on account of the quantities of jewels he wore, with many precious stones around his neck as well as spinels, emeralds and pearls on his arms, and diamonds hanging from his turban" (Jaffer, 2013) (figure 6). This is confirmed by later portraits of the emperor that show him draped in pearls, gemstones, and rings.

Early in the Mughal era, jewels were used as gifts on rare occasions, but only for the most special of royal guests. They were bestowed at feasts and celebrations. But starting with Jahangir and following with Shah Jahan, gift giving became an important political and cultural practice, layered with many intricacies. These two leaders also embraced European and Asian craftsmen, which is evident in the types of gems and jewelry they collected and later in the style of the architectural gem inlay work they adopted. In 1615, at the "Feast of the Water Aspersion," an array of gemstones and jeweled utensils was offered (Melikian-Chirvani, 2004).

Gifts were also given to commemorate the transfer of power, as when Shah Jahan became governor of Bengal and received a jeweled sword belt. A jeweled dagger belt was given to the great grandson of the founder of the Safavid dynasty (Shah Ismail I of Iran) by the governor of Zamindawar on a similar occasion in 1593. During the rule of Shah Jahan, gold decanters enameled and encrusted with gems were given at the annual Rosewater Celebration (Melikian-Chirvani, 2004).

Islamic law (see figure 7) prohibited men from wearing gold jewelry, but this was generally not enforced during the Mughal period in India except under the reign of Shah Jahan's son Aurangzeb, from 1658 to 1707. Mughal rulers were influenced more by the Hindu tradition of adorning themselves with gold jewelry than by Persian traditions. Jahangir was known for wearing strung jewels such as pearls and

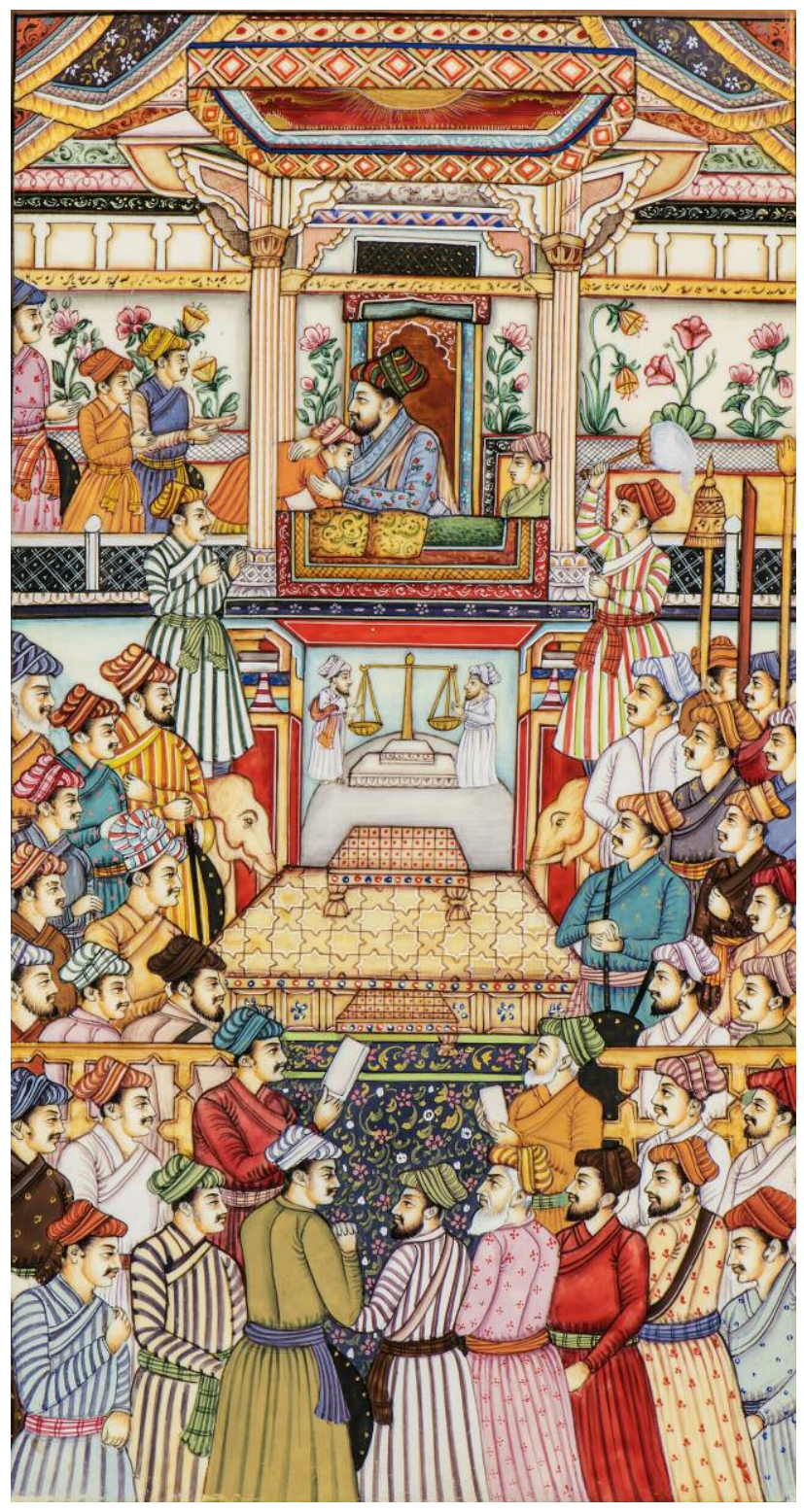

Figure 7. This seventeenth-century miniature painting on ivory depicts Shah Jahan in his durbar (court) and the al-Mizaan (Islamic scales of justice). Photo by Robert Weldon/GIA.

strands of gemstones, as well as jeweled turban ornaments, as evidenced by writings and paintings of the era. Shah Jahan's own devotion to jewelry started well before his reign. In a portrait from 1617, he is wearing pearls and bracelets and holding a jeweled turban ornament. In portraits as emperor, he is draped in gemstones and gold, and in some paintings depicted on bejeweled thrones, including the famous Peacock Throne (Jaffer, 2013). 


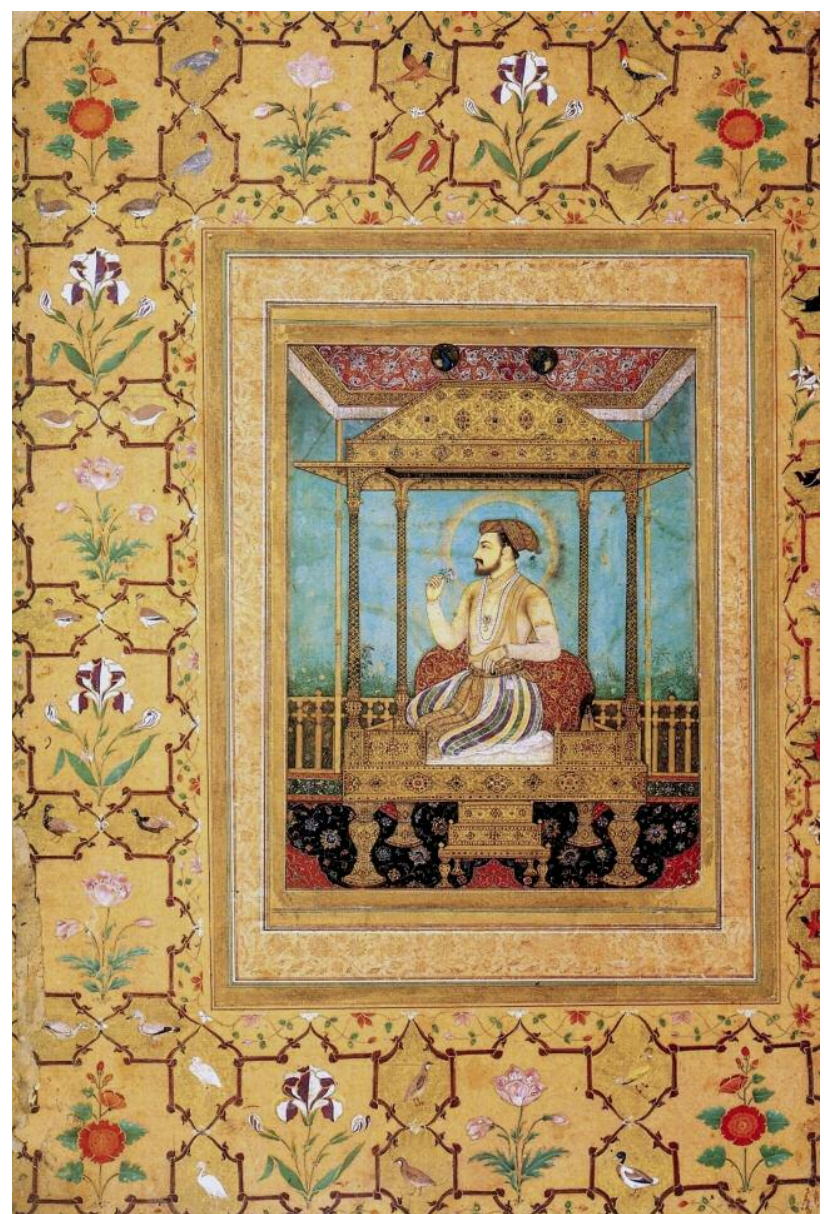

Figure 8. A painting of Shah Jahan on the Peacock Throne. The painting is attributed to the noted Mughal painter Govardhan, circa 1635.

From 1707 to 1739 , following the reign of Aurangzeb, Mughal laws gave the emperor and certain noblemen exclusive ownership of gemstones over 5 carats, as well as jewelry. Earrings and lengthy strands of pearls and gemstones, turban ornaments, amulets, finger rings, archer's rings, belts, and jeweled weapons were part of that wealth and power (Jaffer, 2013). They also had the exclusive right to bestow jewel-encrusted weapons and turban ornaments, of which the latter were especially popular gifts.

Some of these extravagant jewels were distributed to the needy in a Hindu tradition that began during the reign of Akbar and ended with Aurangzeb. At the emperor's biannual birthday weighing ceremony, which happened on his lunar and solar birthdays, his weight (and the weight of royal princes) was measured against expensive fabrics and gemstones. The monetary equivalent of this weight was given to the poor. With Aurangzeb's reign, the lavish ceremonies and patronage of the arts that took place under previous emperors were drastically reduced.

According to the writings of French traveler and gem merchant Jean-Baptiste Tavernier (1605-1689), who made six voyages to Turkey, Persia, and India in search of gems and treasures, there was a particular protocol in gift giving. Aurangzeb would have merchants sell gemstones and jewelry from the imperial treasury to nobles, and these items would then be gifted back to the emperor (Tavernier, 1678). The political nature of these gifts endowed the giver and the receiver with symbolic gestures, while ensuring that the Mughal rulers retained their valuable treasures.

Pearls, too, were highly valued. The Mughal emperors preferred round pearls, whereas baroque pearls were popular in Europe at the time. The appreciation for pearls is evidenced by their ubiquity in paintings and sculptures (Bala Krishnan and Sushil Kumar, 2001). Despite their passion for pearls, emperors such as Shah Jahan treasured richly colored emeralds even more. Emeralds from South American deposits, which had been discovered by Europeans in the late 1500s, made their way to India. These were often carved with floral motifs and Islamic inscriptions. Such items were given as gifts by the emperor and the royal court (Lane, 2010).

This all came to an end when the Persian ruler Nadir Shah (r. 1736-1747) sacked Delhi in 1739. Much of the Mughal wealth, including the fabled Peacock Throne (figure 8), was taken to Persia and added to what would become the Crown Jewels of Iran. This was the first of several times the Mughal capital fell and its riches were taken away. With the collapse of the central authority, the declining Mughal Empire splintered into autonomous states and finally dissolved in 1857 (Jaffer, 2013).

Enameling in the Mughal World. Although enameling dates back to the Egyptians and Sumerians prior to 2500 BCE (Sharma and Varadarajan, 2004), it reached new heights under the Mughal rulers. It was during this period that the most outstanding pieces were produced. The first reference to enameling in India was under Akbar's reign during the sixteenth century, in Mubarak's account Ain-i-Akbari (1894), which mentions the enameling of "cups, flagons, rings and other articles with gold and silver." The art of enameling spread throughout India, including among Hindus, beginning in Multan (in modern-day Pakistan) and Lahore, extending from workshop to workshop, circulating to Jaipur and other cities. 

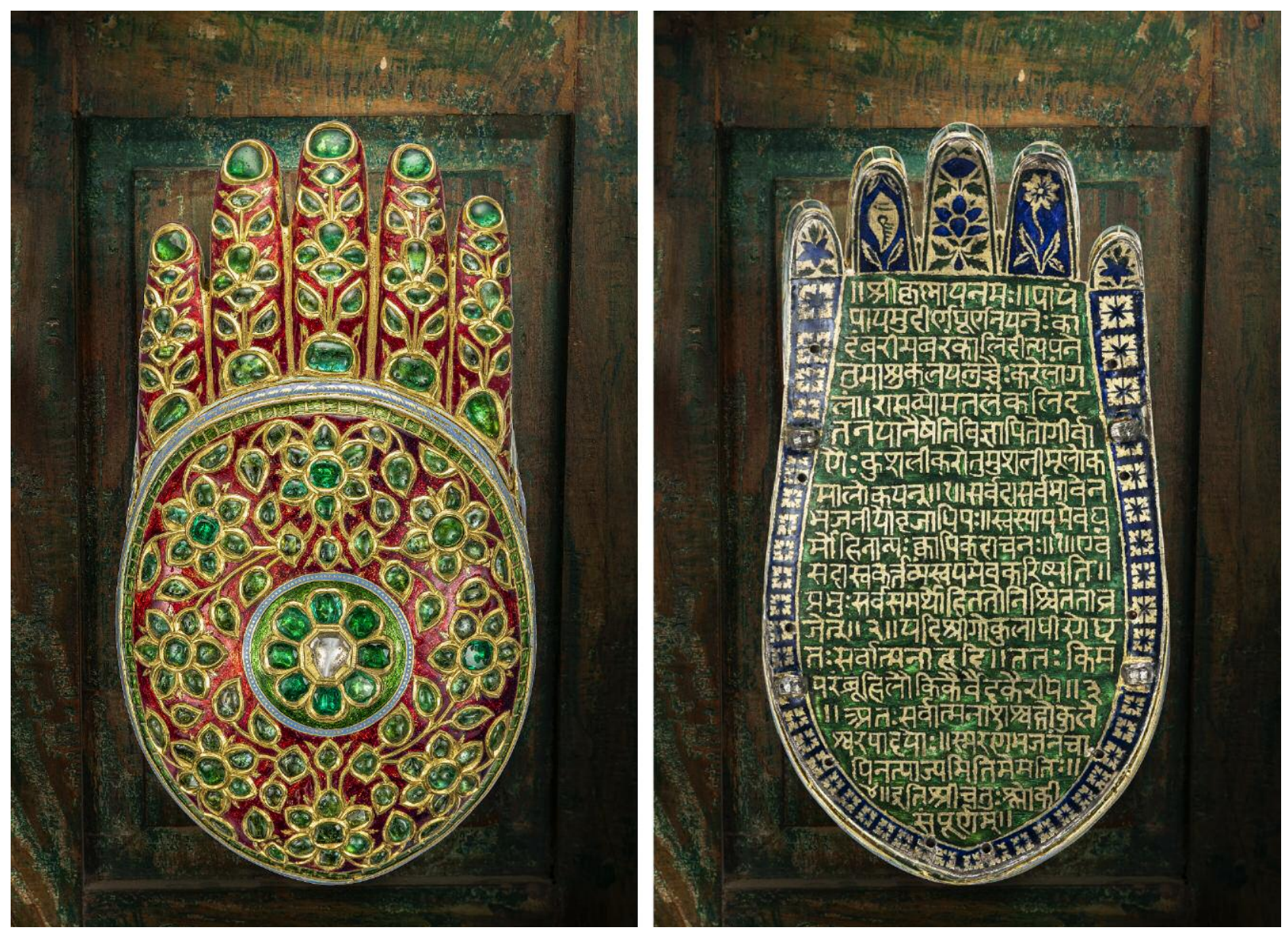

Figure 9. This seventeenth-century hand of Vishnu with exquisite enameling from Maharashtra contains Colombian emeralds and Indian diamonds set in $22 \mathrm{~K}$ enameled gold, illustrating a popular enameling style. The hand measures $14 \times 8 \times 1.5 \mathrm{~cm}$. The inscription on the back, in Sanskrit, quotes devotional verses from the Bhagavad Gita. Photos by Robert Weldon/GIA. Courtesy of private collectors.

According to Sharma (2004), "the style during [the Mughal] period, and used by Hindus as well, was to decorate the frontal side of the ornaments on an enameled background with precious gems while the reverse was adorned with enameled patterns.... This effortless blending of Muslim and Hindu decorative art in the realm of jewellery made these pieces stylistically unique." The back was often as beautiful or more beautiful than the front (figure 9).

The style of Mughal-era enameling, most likely adapted from the South Indian Deccan enamelers, shares common themes with the decor of the Taj Mahal, which features red poppies and floral patterns on a white background. This style is a hallmark of Jaipuri enamelwork. Jaipur was the center of Indian enameling during the eighteenth and nineteenth centuries. The advancement of Jaipur as an important enameling capital was a result of close ties with the Rajasthani Rajputs and the Mughals (Sharma, 2004).

It was under Shah Jahan's reign that enameling began to flourish. Jahan was truly a connoisseur of all things artistic. Through enameling he could combine his appreciation for gemstones, art, and architecture. He used enameling to embellish some of the finest thrones, such as the Peacock Throne, as well as magnificent decorative objects and weaponry (Sharma, 2004).

With the Taj Mahal, Shah Jahan displayed the enameling of the Mughal period most consummately and passionately. While the Taj Mahal was still under construction, he had a golden screen created. It contained enameled inscriptions and cupolas that were to be placed around Mumtaz Mahal's tomb on the second anniversary of her death (Bala Krishan, 2001). 
Shah Jahan, the Gem Connoisseur. The incredible gem wealth available to Shah Jahan made it possible for him to decorate the Taj Mahal with his vast collection of gems, jewels, and jeweled objects. Some highlights from Shah Jahan's collection were inscribed gems. Early on, Indian gem cutters mastered the technique of drilling gems with diamond points and inscribing them to mark ownership by the Mughal elites (S.H. Ball, 1931). The inscriptions follow an imperial regal style and include important dates (Jaffer, 2013). One famous diamond, known as the Shah diamond, has three separate inscriptions reading "Burhan Nizam Shah, 1591"; "Shah Jahan, 1641"; and "Fath Ali Shah, 1824" (Haidar and Stewart, 2014). This $88.71 \mathrm{ct}$ table cut was later presented to Czar Nicholas I in 1829 by an Iranian prince. The Shah diamond is now part of the State Diamond Fund, housed in the Kremlin Museum in Moscow.

Another favorite gem to inscribe was spinel. Necklaces of inscribed spinels were painstakingly assembled by the Mughals. A $54 \mathrm{ct}$ spinel auctioned by Sotheby's in London in April 2017 contained the names of Jahangir, Prince Khurram, and Aurangzeb and was dated 1615 and 1659. While the estimate was $\$ 77,000-\$ 103,000$, the realized price was more than $\$ 330,000$. Sotheby's catalog described the spinel as a "pinkish stone...pierced through the centre and set with a later gold chain and hanging seed-pearl and metal-thread pendant."

A remarkable inscribed spinel necklace appeared in the June 2019 Christie's New York auction "Maharajas \& Mughal Magnificence," featuring gems and jeweled objects from the Al Thani Collection. The seven spinels are dated by Persian inscriptions ranging from 1607 to 1608 and 1754 to 1755 (figure 10). These inscriptions include la'l-I jalali ("glorious spinel") and name Akbar, Jahangir, and Shah Jahan, among other emperors. With a reserve of $\$ 1,000,000-\$ 2,000,000$, the necklace fetched a final price of $\$ 3,015,000$. Spinels were held in the highest esteem, equal to that of rubies and emeralds, and were chosen by the Mughals to bear imperial names.

The timelessness of Mughal splendor is seen today in the enthusiasm for this auction. The 400 lots generated $\$ 109,271,000$, the highest total for any auction of Indian and Mughal objects, and the second highest for any private collection. In 2020, nearly 6,000 pieces from the $\mathrm{Al}$ Thani Collection, assembled by Sheikh Hamad bin Abdullah Al Thani of the Qatari royal family, will go on exhibit at the Hôtel de la Marine in Paris as a permanent museum collection and education facility.

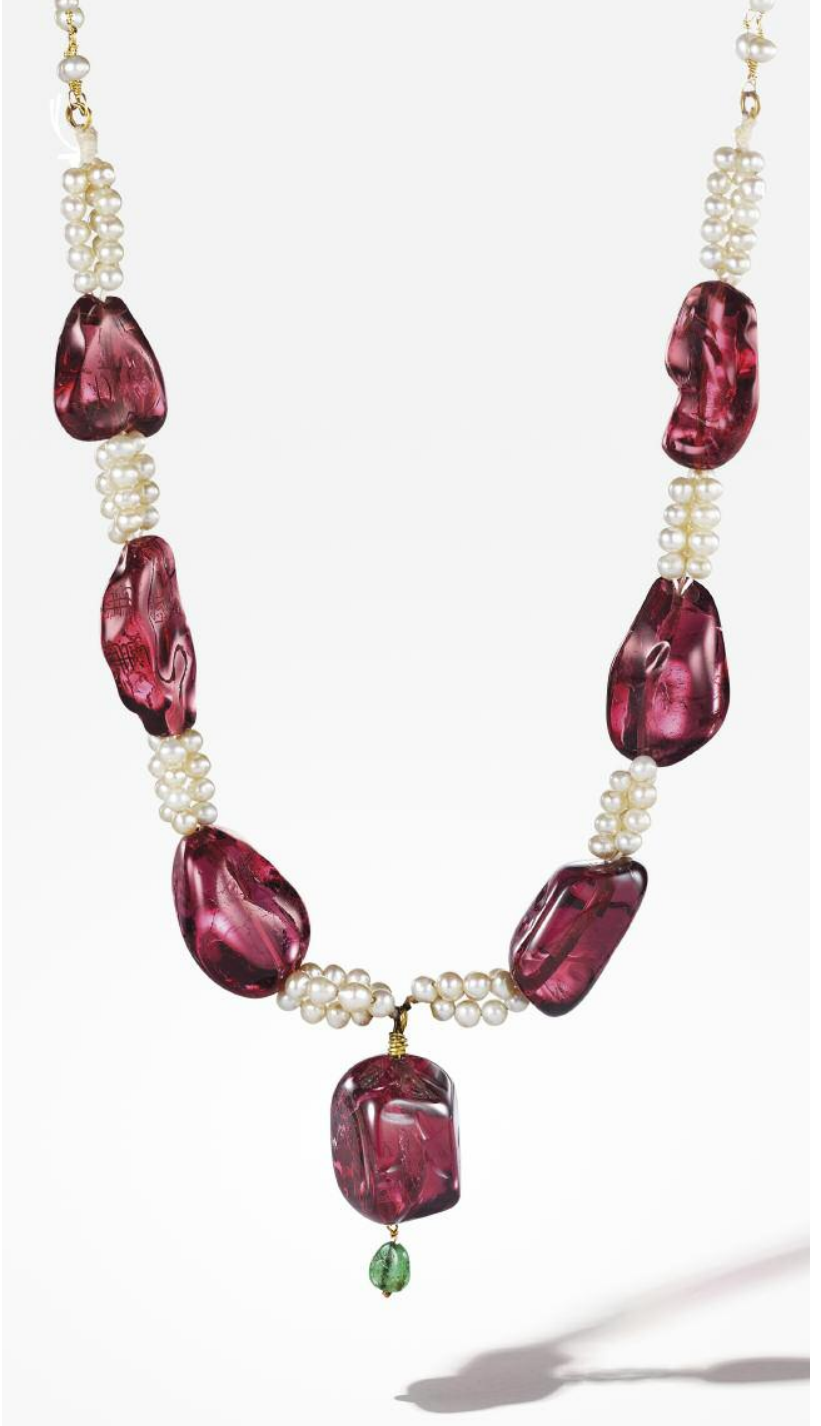

Figure 10. This seventeenth-century necklace containing seven spinels, pearls, and a pear-shaped cabochon emerald drop, set in gold, is inscribed in Persian with Mughal emperors' names. It was sold by Christie's New York in June 2019 for \$3,015,000. Courtesy of Christie's.

\section{TRADE ROUTES FOR GEM MATERIALS}

To understand how such gem wealth, gold, and silver were available to the Mughals, one needs to review the regional powers of Asia in the fifteenth and sixteenth centuries. Gem traders came from around the world, driven by their passion for acquiring what India produced, as well as the goods that flowed through Indian trade centers. Indian trade followed ancient land and sea routes. The routes became more complex as brave travelers ventured into new locations with a more sophisticated understanding of trade winds and navigation. New trading centers arose as others declined. Shah Jahan acquired his vast collection of jewels for the Taj Mahal largely because of the key role India played in the global gem trade. 
Some of the key trade routes are shown in the world trade route map on pp. 304-305.

The ancient trade routes included the Silk Road, which had been used for thousands of years. UNESCO has identified 12 sites in India along the Silk Road. Rivers throughout India also provided an inexpensive means to move people and goods. It is no accident that Agra and the Taj Mahal are situated next to the Yamuna River, an important route. Other factors also contributed, such as

globalized international trade that brought such wealth to the Mughal ruler that he was able to contemplate this extraordinary gesture to his beloved spouse. [Shah Jahan's] ability to complete [the Taj Mahal] stemmed from the profound shifts in the world's axis of power, for Europe and India's glory came at the expense of the Americas....Gold and silver taken from the Americas, and from Africa, found their way to Asia through trade: it was this redistribution of wealth that enabled the Taj Mahal to be built (Frankopan, 2017).

The influx of South American emeralds, and the expanding European trade in these goods, coincided with Mughal appreciation for the gem. This was underscored by the Prophet Muhammad's favoring of the color green. Finer emeralds had never been seen, and the sheer volume of them provided Jahangir and Shah Jahan with exceptional trading possibilities. Emeralds from Egypt had been mined up until medieval times. According to Lane (2010), emeralds from what is now Pakistan and Afghanistan provided occasional supplies through trade along the Silk Road. But nothing compared with the quality and quantity of South American emeralds.

One of the most fascinating trade routes at this time brought emeralds from the present-day Colombian mining areas of Chivor and Muzo, mined since pre-Columbian times, to India and the Mughals (Weldon et al., 2016) (figure 11). Lane (2010) describes how these emeralds traveled across the Atlantic and Indian Oceans through new Christian, Jewish, and Sephardic family networks to Seville, Antwerp, and Lisbon. Later, Jewish Ashkenazi families became active in this commerce, and gems were transported by land and by sea from Mediterranean and European cities. Traded along with the emeralds were pearls from the New World, Baltic amber, Mediterranean coral, and Mexican pearls and silver from Potosí (modern-day Bolivia). These were exchanged for spices, silk, and porcelain, as well as diamonds, rubies, sapphires, and other gem materials. Armenian merchants were particularly successful with the ruby trade from the city of Pegu (in modern-day Myanmar), then under Persian Safavid protection. The

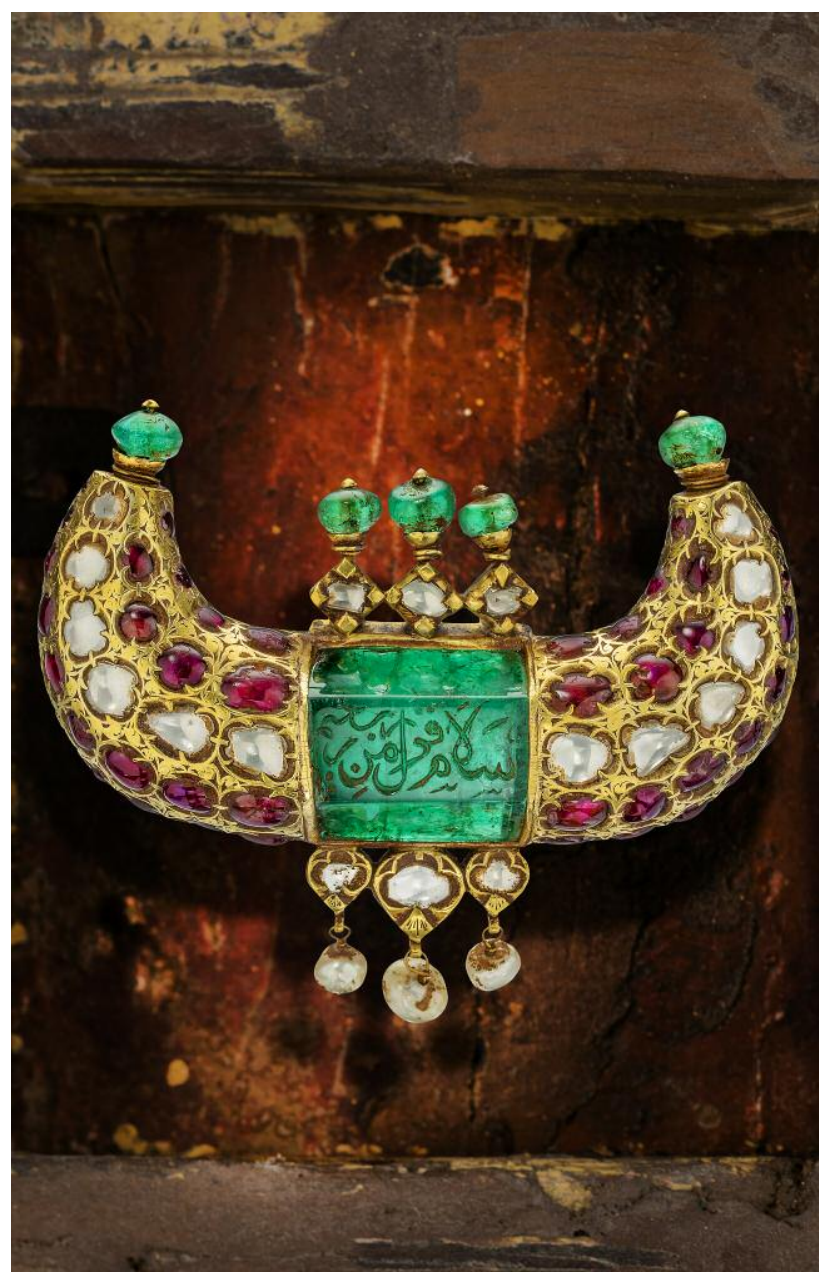

Figure 11. The centerpiece of this Mughal horn pendant is a 125 ct Colombian emerald engraved in Arabic with salutations of peace based on a verse from the Koran. It dates back to the eighteenth century. The pendant also contains ruby, diamond, and pearls set in $22 \mathrm{~K}$ gold and measures $6 \times 8.5 \times 2 \mathrm{~cm}$. Photo by Robert Weldon/GIA. Courtesy of private collectors.

great demand for silver established another route from Mexico to Manila. Tavernier also describes the trade of emeralds from Peru (mined from Muzo and Chivor). Gold, silver, and rough emeralds were traded through Manila (Tavernier, 1678). Modern gem testing has confirmed the origin in many such examples (Weldon et al., 2016).

The port city of Goa, located in Panaji State on the Indian Ocean, is $1,667 \mathrm{~km}$ (1,036 miles) from Agra. As Emilio Rui Vilar relates in the introduction to Goa and the Great Mughal:

Following the arrival of the Portuguese in India (1498), the newcomers were forced into a complex web of strategic moves and political alliances that guaranteed 


that they could sail, trade, and carry out missionary work in safety and ensured the security of their settlements and trading posts....not only stimulating trade, diplomatic contacts and missionary work, but also mutual associations and influences in the fields of culture and the arts (Vassallo e Silva and Flores, 2004).

With the emergence of Goa as a trading center, the emphasis shifted there (Vassallo e Silva and Flores, 2004). The capital of the Portuguese state of India, Goa had become a major trading center for importing goods and exporting decorative arts by the late 1500s. Gemstones and jewelry were leading items in the luxury trade. Interestingly, it was the relative freedom for foreign merchants, a favorable tax status, and other trade concessions that gave rise to the growth of Goa. Tavernier, the jeweler merchant to Louis XIV of France, wrote of its significance:

Goa was formerly the place where there was the largest trade in all Asia in diamonds, rubies, sapphire, topaz and other stones. All the miners and merchants were there to see the best which they had obtained at the mines, because they had their full liberty to sell, whereas in their own country, ... they were compelled to sell at whatever price was fixed (V. Ball, 1977b).

Just as a variety of gems entered Goa from global sources, this port also became the principal center for gemstones heading west, especially diamonds (Bala Krishnan, 2001).

Figure 12. A recent scene at a camel fair in Pushkar, Rajasthan, India, shows that the trading of camels has changed little since the Mughal time. Photo by Robert Weldon/GIA.

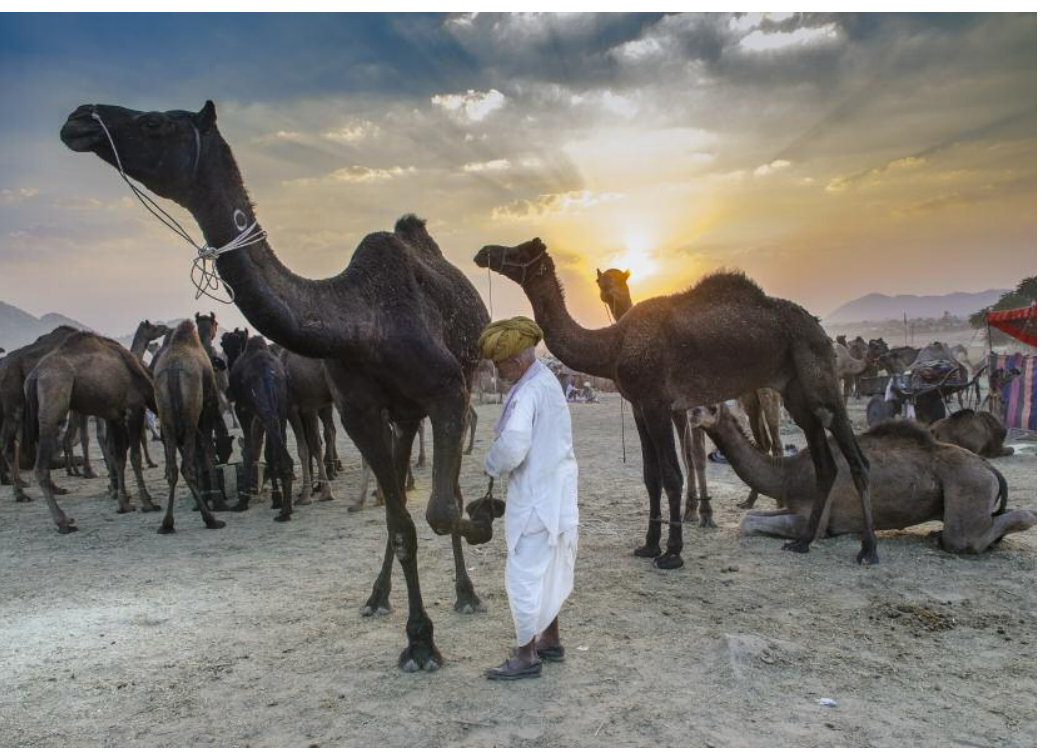

As Tavernier describes, value-added businesses began to emerge in the thriving port, employing a multicultural and diverse contingent of craftspeople. It became famous for its Portuguese lapidary operations. The street called Rua Direita was the center for many workshops and stalls of jewelers, silversmiths, and lapidaries (V. Ball, 1977b).

The Importance of Gem Trade from Goa to Agra. Because of the Mughals' insatiable desire for gems, precious metals, and decorative arts, the trade route from Goa to Agra became well established. An equally insatiable appetite for diamonds from the Golconda mines drove explorers and merchants to India, helping establish trade. There was no other place on earth to acquire diamonds of significant size and quantity. The success of the Portuguese in bringing all manner of precious goods to Goa made this possible. According to the Flemish merchant Jacques de Coutre, "It is very true that from all parts of the World, they send pearls, emeralds, rubies, and jewels of great value to Eastern India, and we all know full well that they came to the Mughal" (Vassallo e Silva and Flores, 2004). During de Coutre's 32-year career in India, he and his brother dealt in precious stones and jewels. He knew that the important gems ended up in the Mughal treasury. According to the early seventeenthcentury Italian explorer Francesco Carletti:

The Great Mughal purchased all the spinel rubies from all over the world, as these gems brought high profits when sent on for sale in India. The consumption and aesthetic demands of the Mughal Empire required a constant flow of goods, jewels, and countless rarities that only a port such as Goa could properly supply (Vassallo e Silva and Flores, 2004).

Just as early scholars wrote about the port of Goa, modern archaeologists and other scholars have documented the growth and decline of other regional trading centers (see trade route map on pp. 304-305). Intricate maps and chronicles of these sites paint a picture of the goods and products traded (Thoresen, 2017). Gold, ivory, and rock crystal-as well as slaves_came from Africa. Silks, spices, gems, silver, and gold were traded between Asia and the Americas, while furs and gems came from Russia.

In addition to spinels, emeralds, pearls, rubies, and other gems, Tavernier described the large diamonds recovered from India. He visited four diamond mines around Golconda: Rammalakota (Roalconda), Kollur (Coulour or Gani), Soumelpour in the kingdom of Bengal, and Kistna (between Rammalakota and Kollur). This information is found in Ball's Volume II of 


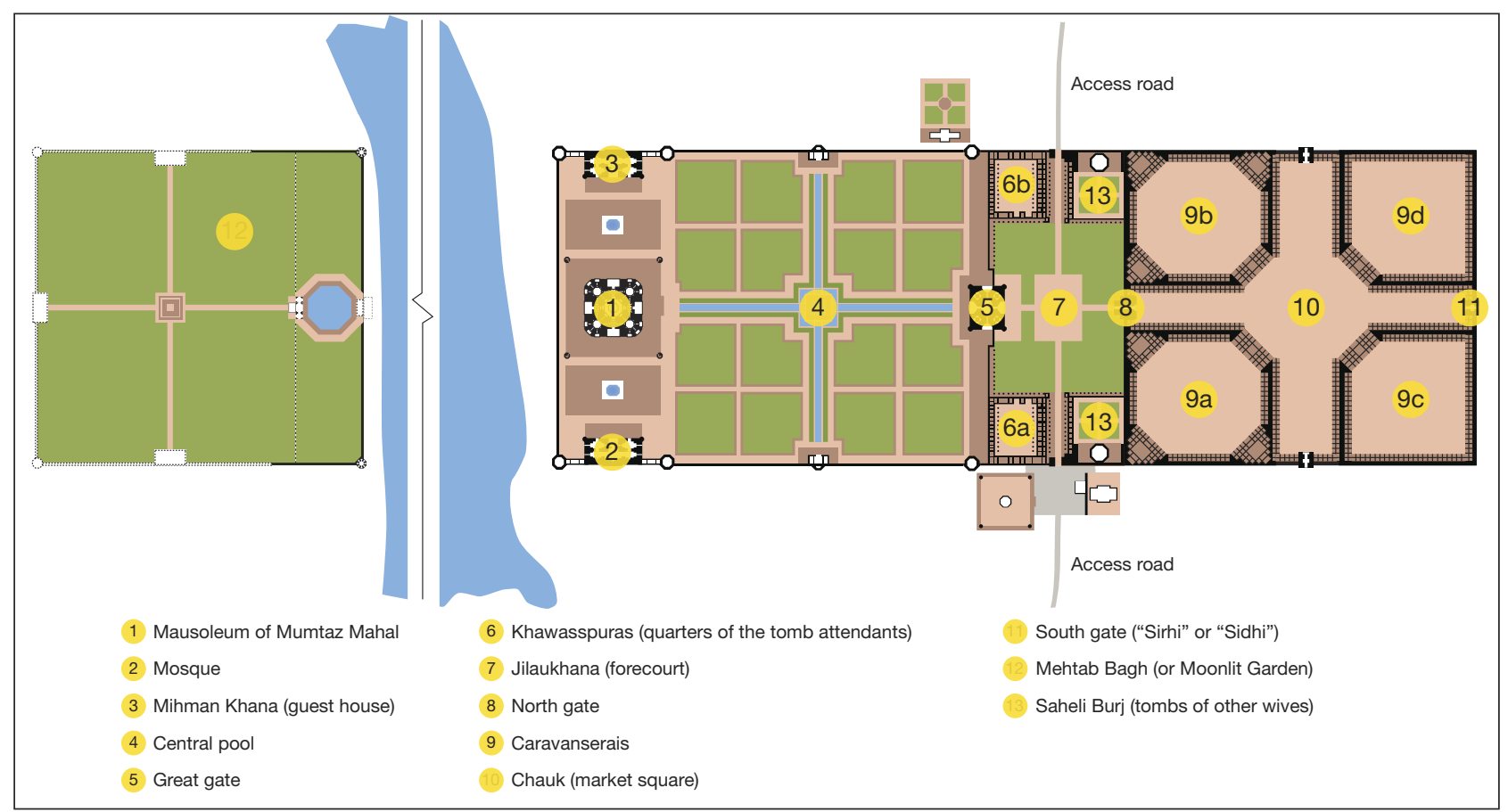

Figure 13. This diagram shows the symmetry of the architecture, reflecting pools, and gardens of the Taj Mahal. Courtesy of I. Mcginnly, Wikipedia Commons.

Travels in India by Jean-Baptiste Tavernier (based on Tavernier's 1676 French edition). Ball (1977a) pointed out the challenges of following the names of the diamond mines given by Tavernier. Ball included an appendix with a list of Indian diamond mines, with latitudes and longitudes. He reproduced Tavernier's famous plate that shows the 20 diamonds he sold to the French king upon his return. This includes the rough now believed to be the French Blue, which was eventually cut into the Hope Diamond. There are also Tavernier's depictions of the Great Mogul, the Golconda, the Grand Duke of Tuscany, and the Bazu.

Travel was by camel caravan. The number of camels in a caravan could vary from several hundred to several thousand (figure 12). Two species were popular along the Silk Road. The Bactrian camel was used for the eastern trade roads and their cold climates in Central Asia and Mongolia. Arabian camels were used for warmer climates on the western routes. Camels were the ideal pack animal, able to carry more weight than horses or donkeys. They carried more than 300 pounds each and required much less water. Without water, a loaded camel could travel for nearly 15 days. Sometimes breeders would crossbreed the two camel species for even greater endurance.

This confluence of international trade, art, and building techniques contributed to the uniquely complex and iconic structure that the Taj Mahal re- mains today, 366 years since its completion. In the next section, we analyze the architecture of this Wonder of the World and the gem materials that were used to adorn her.

\section{ARCHITECTURE AND GEM MATERIALS OF THE TAJ MAHAL}

The mausoleum is the iconic part of the Taj Mahal, but it makes up only a portion of the complex. The entire complex occupies 66.62 acres (0.27 square $\mathrm{km}$ ), while the preserved complex takes up just under 42 acres (169 square $\mathrm{km}$ ). The names of the architects are not known with certainty, but several architects are believed to have worked on the project. Of those, Ustad Ahmad Lahauri and Mir Abdul Karim are the two most often mentioned (Koch, 2006) (figure 13).

The grounds of the Taj Mahal are accessed through the forecourt (Koch, 2006), a large courtyard with the east and west gates. It was used for ceremonial purposes, such as marking the anniversary of the death of Mumtaz Mahal. The tops of the gates slope up in the center to a rectangular structure called a pishtaq. Within this shape sits an archway through which the complex is entered. While the inner facade of the archway is quite embellished, the outer face is simpler, with some floral ornamentation on the spandrels (the two triangular spaces between the top of the arch 

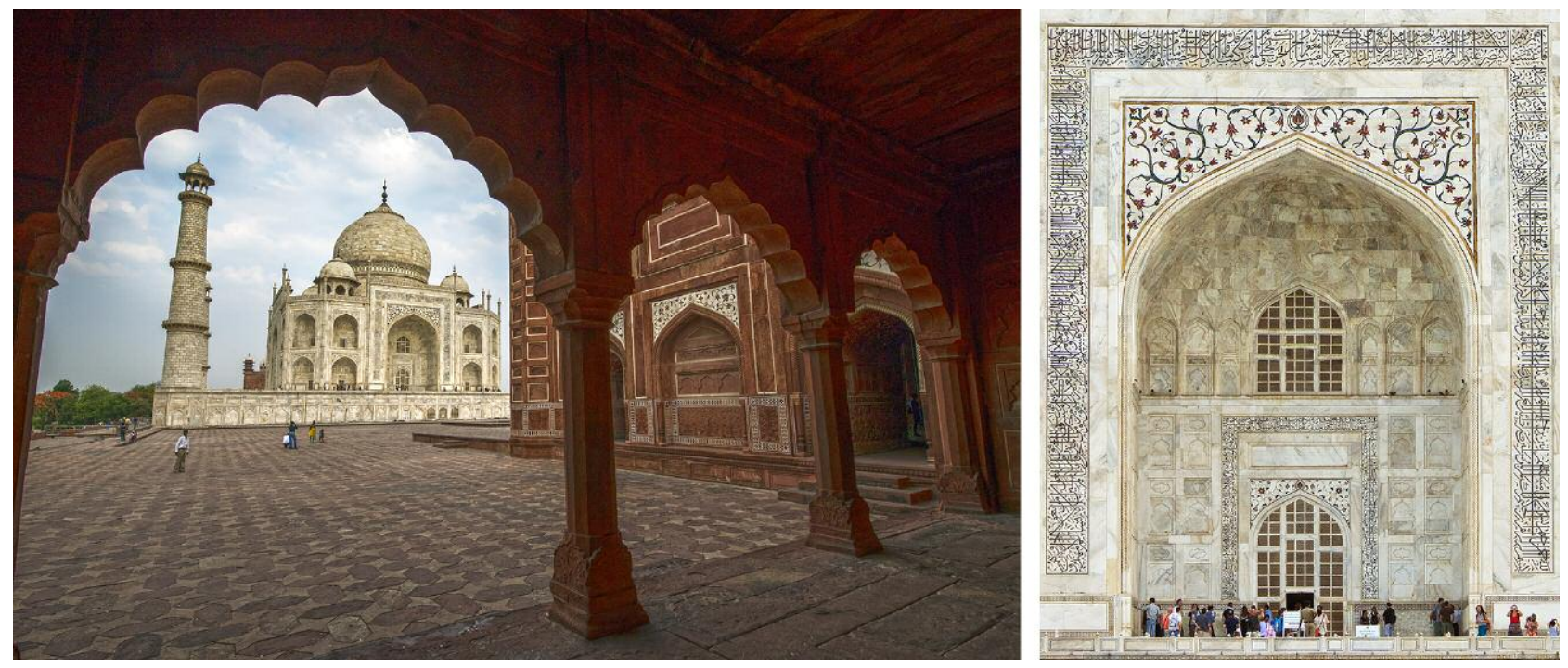

Figure 14. Left: A view of the Taj Mahal from the Mihman Khana, or guest pavilion. Right: A view of the inscribed entryway, called a pishtaq, with floral embellishment on the spandrels. Photos by Robert Weldon/GIA.

and the rectangular frame) (figure 14). Unlike the detailed inner facades of the east and west gates, both the inner and outer facades of the south gate are simple in ornamentation (Koch, 2006).

The Great Gate is the centerpiece of the forecourt, located on the southern wall within the funerary garden, a symmetrical garden divided into quarters. The garden once contained fruit-bearing trees (symbolic of life) and herbs. Abundant roses (symbols of love) were mentioned by Shah Jahan's poet, Qudsi, but there were many more unnamed blooms throughout. The reflecting pools are lined with cypress trees, symbolizing death.

The mausoleum sits on a raised square platform standing seven meters high. The dome of the mausoleum is 73 meters high and nearly 18 meters in diameter. Four minarets, towers with domed pavilions, surround the mausoleum.

Two additional tomb buildings, called Saheli Burj, lie along the south end of the complex. They hold the bodies of Shah Jahan's lesser wives. According to the Taj Mahal Museum, Akbarabadi Mahal lies in the western tomb, and Sirhindi Mahal lies in the eastern tomb. Akbarabadi Mahal was a favorite consort in the last reigning days of Shah Jahan and the wife that he spoke highly of to his daughter, Jahanara, in his final moments (Koch, 2006). One of the four tombs contains a marble cenotaph embellished with parchin kari (this technique was only used in the tombs of the emperor's family at the time the Taj Mahal was built), but vandals have stolen many of the more valuable inlaid stones.

Water is a very important part of the garden (figure 15). According to Begley (1979) and the official Taj Mahal website, the garden features four water channels symbolic of the Rivers of Paradise mentioned in the Koran: the rivers of water, milk, wine, and honey. The Archaeological Survey of India is charged with maintaining the trees and flowers of the Taj Mahal. They have done their best to reconstruct the original planting based on the discovery of old plans. However, some of this work amounts to educated speculation.

Significance of the Gems Used. Gems were chosen not only for their color but also for the spiritual properties attributed to them at that time. Of the many different types of gems used in the parchin kari of the Taj Mahal, the most significant in Islamic culture is carnelian (figure 16). The Prophet Muhammad is said to have worn a silver ring set with carnelian on the little finger of his right hand, using it as a seal. Jafar, one of the most well-known of the imams, proclaimed that any man who wore carnelian would have his desires fulfilled (Kunz, 1938).

Jade and chlorite were likely used because green was the Prophet Muhammad's favorite color (Brill, 1993). Some ancient cultures also believed that jade was a healing stone, particularly for the kidneys (Tagore, 1881). Lapis lazuli is another gem that was chosen; the Sumerians believed that anyone who car- 


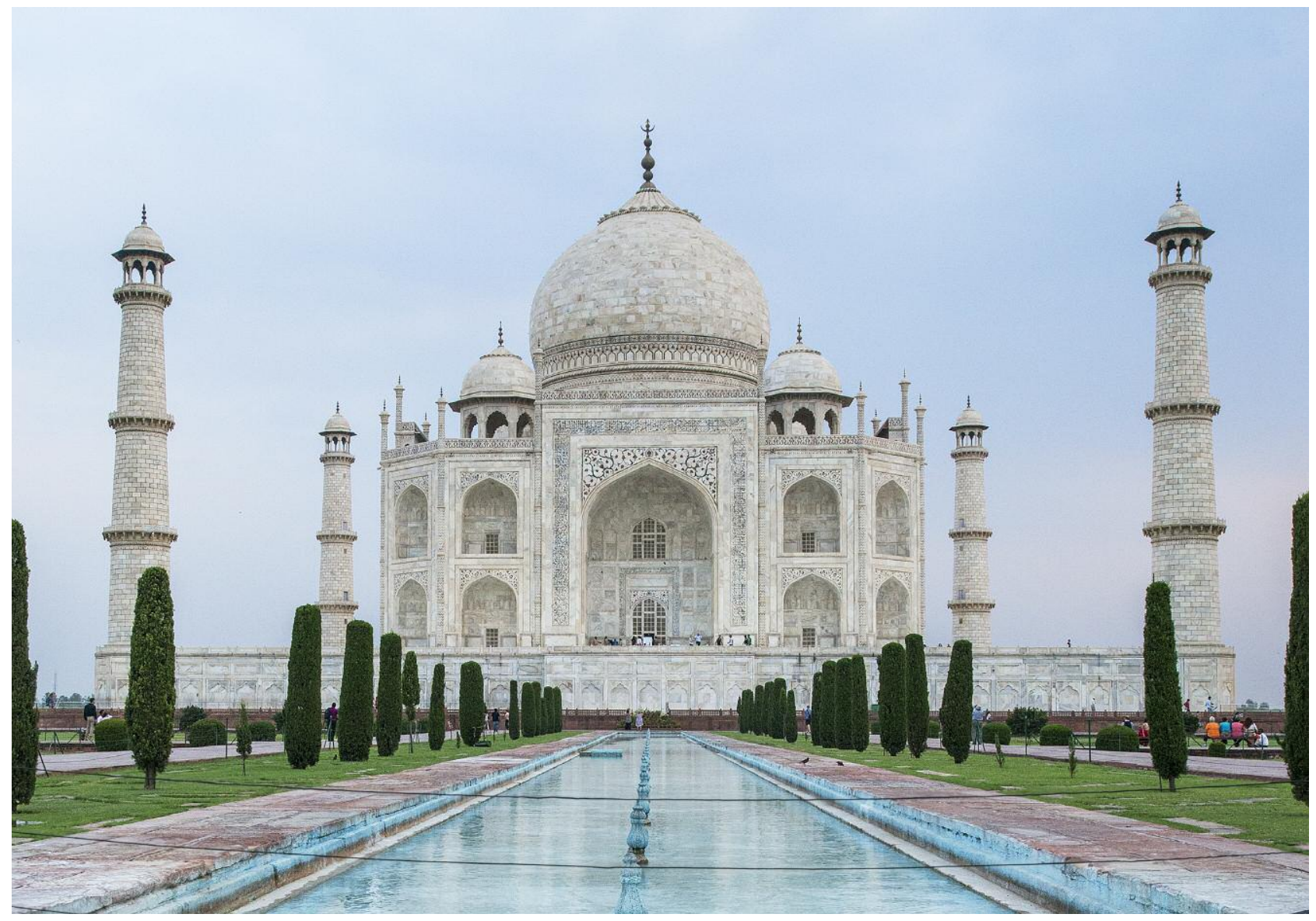

Figure 15. The tranquil reflecting pools add to the symmetry of the Taj Mahal. Photo by Robert Weldon/GIA.

ried an amulet made of this material was in the company of a god (Budge, 2011). It was cherished through-

Figure 16. A close-up of the parchin kari consisting of multicolor chalcedony and other materials set in marble showing a typical floral pattern that decorates the interior and exterior of the Taj Mahal. Photo by Robert Weldon/GIA.

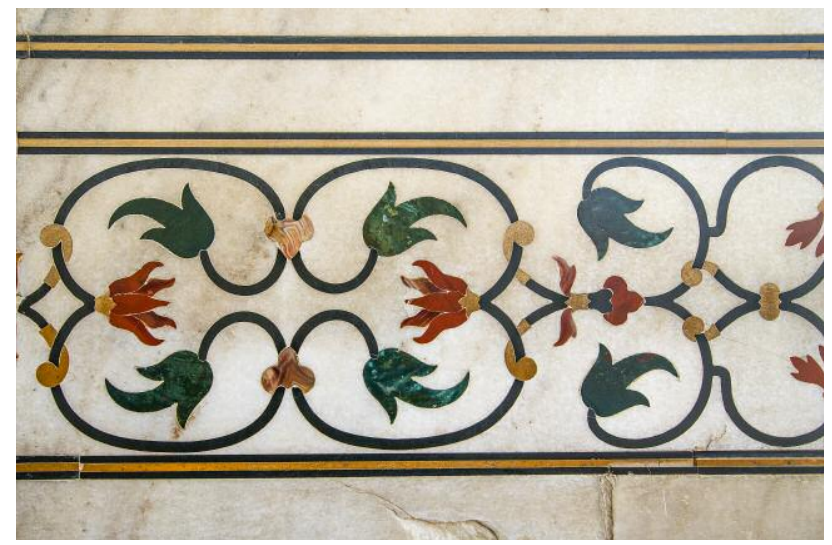

out the ancient worlds of India, Mesopotamia, and Iran, as well as Egypt, where it was used in talismans, particularly of the eye and heart (Thomas and Pavitt, 1993).

In Mesopotamian culture, jasper was associated with the heavens (Horowitz, 1998), as well as driving away evil spirits (Kunz, 1938). Agate and jasper (both chalcedonies) were used as protection against the evil eye (Budge, 1968). Chalcedony was believed to render enemies terror-stricken while also having the power to promote peacefulness (Budge, 1968) and happiness (Tagore, 1881) and dispel sadness (Jones, 1968). Bloodstone was said to have the power to bring rain, a benefit to Shah Jahan's beautiful gardens (Kunz, 1938). It might have been for protection against enchantments and spells that sard was used in the parchin kari. Sard was also believed to bring happiness (Kunz, 1938). Other materials used that might have been chosen for purely aesthetic reasons include green plasma jasper, yellow limestone, variegated limestone, yellow marble, striped marble, and clay slate (Koch, 2006). 
TABLE 1. Types of gem materials used in the Taj Mahal.

\begin{tabular}{|c|c|c|c|}
\hline Farsi & English & Hindi & Early name(s) of the source(s) \\
\hline Yaqut-e-Gulabi & Rose or pink sapphire & Gulabi & Ceylon \\
\hline Hajr-ul-Dum & Bloodstone & Pitunia & India \\
\hline Rukham & Alabaster & Sangmarmar & Makrana, India \\
\hline Yaqoot & Amethyst & Kathela & Moldova, India \\
\hline Nilgoo'n billor & Aquamarine & Beruj & Bihar, India and Ceylon \\
\hline Marmar-e-Seeya & Black marble & Kala sangmarmar & Jhari \\
\hline Aqiq-e-Jegari & Carnelian & Aqiq & Baghdad or Yemen \\
\hline Sang-e-Yemani & Chalcedony & - & India \\
\hline Zaituni Zabarjad & Chrysolite & Laksunia & Nile River \\
\hline Sadaf Halazoni & Conch shell & Sankh & Persian Gulf and Gulf of Mannar \\
\hline Marjan-e-Sorkh & Coral, red & Moonga & Indian Ocean \\
\hline Boloor & Crystal quartz & Billoor & Hyderabad, India \\
\hline Almas & Diamond & Hira & Golconda region \\
\hline Zomorrod & Emerald & Panna & South America and Egypt \\
\hline $\mathrm{La}^{\prime} \mid$ & Garnet & Tamra & Ganges River \\
\hline Sang-e-Tálai & Golden stone & Sunela & Unknown \\
\hline Daarchini yaqoot & Hessonite garnet & Gomed & Ceylon \\
\hline Yashm & Jasper & Margaj & Cambay, India \\
\hline Lajvard & Lapis lazuli & Lajward & Afghanistan \\
\hline Ahan Roba & Lodestone & Maqnatis & Gwalior, India \\
\hline Malaqeet & Malachite & Dhana-i-farang & Russia \\
\hline Marmar & Marble & Sangmarmar & Jaipur \\
\hline Sadaf Morvaridi & Mother-of-pearl & Sip & Persian Gulf and Gulf of Mannar \\
\hline Nafreit & Nephrite & Yashav & Chinese Turkestan \\
\hline Aqiq Suleimani & Onyx & Suleimani & Deccan Plateau, India \\
\hline Morvarid/Dor & Pearl & Mukta/Moti & Persian Gulf and Gulf of Mannar \\
\hline Sang-e-Sorkh & Redstone & Surkh & Gwalior, India \\
\hline Yaqut & Ruby & Manak & Pegu (Myanmar) and Badakhshan (Afghanistan) \\
\hline Sang-e-Maaseh & Sandstone & Bansi & India \\
\hline Yaqut-e-Kabud & Sapphire & Neelam & Pegu (Myanmar) and Ceylon \\
\hline Aqiq-e-Qermez & Sard & Gomedak & India \\
\hline Sang-e-Looh & Slate & Siliyat & Monghir and the ruins of Gaur \\
\hline- & Sodalite & Sodaliti & Afghanistan \\
\hline Laal & Spinel & Naram & Badakhshan, Afghanistan \\
\hline Chasm-e-Babri & Tiger's-eye & Dariyai lahsunia & India \\
\hline Zebarjad-e-Hendi & Topaz & Pukhraj & Ceylon \\
\hline Firoozeh & Turquoise & Firoza & Persia and Tibet \\
\hline \multicolumn{4}{|c|}{$\begin{array}{l}\text { Localities named in Voysey (1825). Descriptions also from Markel (2004). Additional information from Moin-Ud-Din (1905) and } \\
\text { Dayalan (2006). } \\
\text { Farsi translations by A. Sinchawla and Hindi translations from B. Mookim (pers. comms., 2019). }\end{array}$} \\
\hline
\end{tabular}


Types of Gem Materials Used by the Artisans and Collected by the Emperors. Along with the large diamonds it produced, India was a source of rock crystal and agates recovered from the Deccan Traps. Related industries emerged, such as the shaping, processing, and inscribing of diamonds. Spinels were believed to have come from Badakhshan in present-day Afghanistan and Tajikistan, along the Mughal trade routes. Lapis lazuli was mined in Afghanistan. Turquoise originated from Persia, and Iran remains an important source of the gem to this day. Rubies, sapphire, and rock crystal quartz were shipped in from Ceylon (Sri Lanka) and Pegu. Pearls came from the Americas, the Persian Gulf, and from trade at Basra, a crossroads between the East and West. Nephrite was imported from China along with a variety of green opaque stones such as green jasper. Jadeite did not arrive from Burma until later in the nineteenth century. As Markel (2004) points out, nephrite was imported from Khotan and Kashgar in Chinese Turkestan in Central Asia. He also explains that jadeite was not yet used in South Asia and that there were dozens of nephrite jade simulants in use.

Voysey (1825) offered the first detailed description of the inlaid stones used in the parchin kari of the Taj Mahal. Over 40 different gem materials used for inlay have been referenced in the literature. Moin-Ud-Din, a general superintendent in Agra in 1905, expanded greatly on Voysey's list with his 120-page study of materials used at the Taj Mahal, which included an itemized table. More recent authors such as Dayalan (2006) have added to the list (see table 1).

A fascinating area of potential study would be to apply modern gemological techniques and advanced instrumentation to known examples of Mughal gemstones and jewelry. Trained gemologists would be able to contrast them with gems from modern sources. Comparative inclusion studies, advanced chemistry, and other techniques that aid in origin determinations would add greatly to our understanding of gems from this era.

Source of the Building Stones and Construction Materials. The Taj Mahal was built on a marble platform over a sandstone foundation. The buildings are brick overlaid with a veneer of marble that was brought in from the Makrana quarries in Rajasthan in western India, nearly $400 \mathrm{~km}$ from Agra. These quarries are famous for their milky white marble. Stretching more than $22 \mathrm{~km}$, they were open-pit mines using traditional labor-intensive methods of excavation. The stones were cut into blocks and transported by oxcart to Agra. Voysey (1825) wrote that the red sand- stone came from Fatehpur Sikri, $35 \mathrm{~km}$ west of Agra. Red sandstone was used to create the mosque and guest pavilion. Balasubramaniam (2009), in his study about the architects of the Taj Mahal, expands on Voysey's observations to include the nearby Rupbas and Tantpur quarries as sources.

Expertise of the Craftsmen. The craftsmen working with minerals and gem materials on the Taj Mahal fell into several groups. First there were the bricklayers and stonecutters, called raj and sangtarash, respectively. According to Ebba Koch, an architectural historian and author of a seminal work on the Taj Mahal, the stonecutters were paid for each linear yard of stone they cut. They left symbols and sometimes Hindu or Arabic names on the bricks. Next came the stone carvers or munabbatkar, who carved the moldings in the rooms and created the exquisite renderings of plants and flowers in sandstone and marble. At the time, Indian artisans were often guided by European experts. Balasubramaniam (2009) writes:

While the supervision and superintendence may have been of people of foreign origin, the current study proves that the actual engineering of the complex was the accomplishment of the genius of local Indian talent... [This proves] that the ultimate realization of the wonderfully engineered construction of Taj was possible due to the engineering abilities and skill of native architects and artisans, as confirmed by their adherence to the traditional measurement units of the subcontinent.

Such traditions have continued to the present day. Koch (2006) illustrates one man, Hajii Nizamuddin Naqshbandi, who did stone restoration at the Taj Mahal for more than 40 years until his death in 2005. He was a follower of the Naqshbandi Sufis and continued the long tradition of Sufi craftsmanship in the building arts (figure 17).

Next came the craftsmen who did the stone inlay. This simple form of intarsia has been used for decorative objects and decor for centuries. It is based on inlaying colorful minerals into a recess to create a mosaic-like pattern. In India the term parchin kari is used both for the simple form of inlay as well as the intricate examples found throughout the Taj Mahal. A master artist known as the parchinkar would first draw the pattern in henna dye on the marble's surface. Then the artist would carve out a space in the marble and fill it with thin polished pieces of gem materials, affixing them with organic glue. The stones were grooved so they would fit together, making the contact between them almost invisible. The technique is still used to this day (figure 18). 


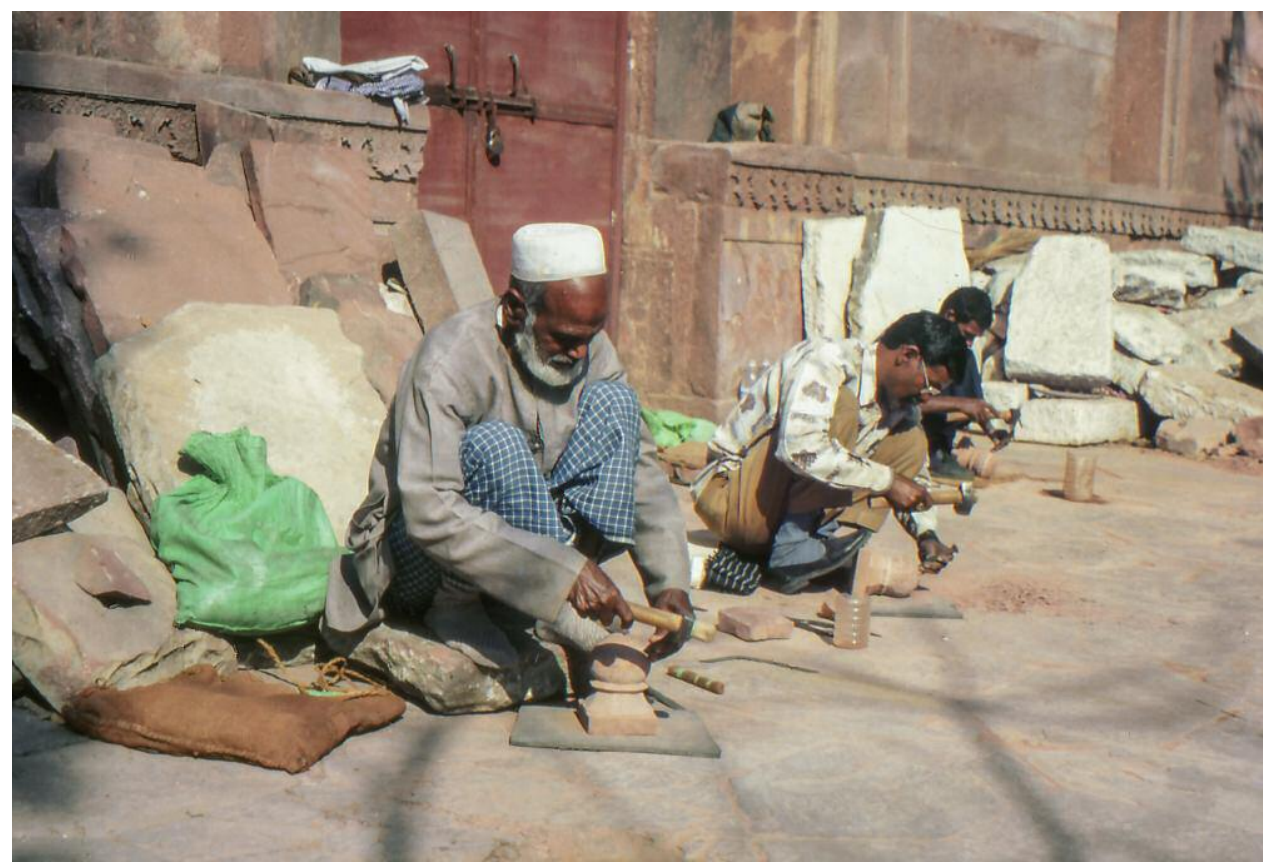

Figure 17. Hajii Nizamuddin Naqshbandi, with other stone carvers, using hammer and point chisel. He worked at the Taj Mahal for more than 40 years and was still employed there when he died in 2005. Reproduced with permission of Ebba Koch, 2006.

In advanced inlays, slivers of different gem materials were artfully placed in the space with a view toward creating colors and shapes of the desired geometric patterns or floral designs. A bow saw coated with abrasives was used to fashion the slivers (figure 19). The technique was mastered by Shah Jahan's lapidaries, and one art historian notes that the "complexity, subtlety and elegance of their work far surpasses that of the Italian artists" (Koch, 2006). Most historians credit the Italians with creating this technique in Florence, where it was called commesso di pietre dure ("composition of hard stones") and often abbreviated to pietra dura (see box A). European artists brought the technique with them to

Figure 18. Modern inlay workers creating parchin kari objects for tourists in Agra near the Taj Mahal. Photos by Robert Weldon/GIA.
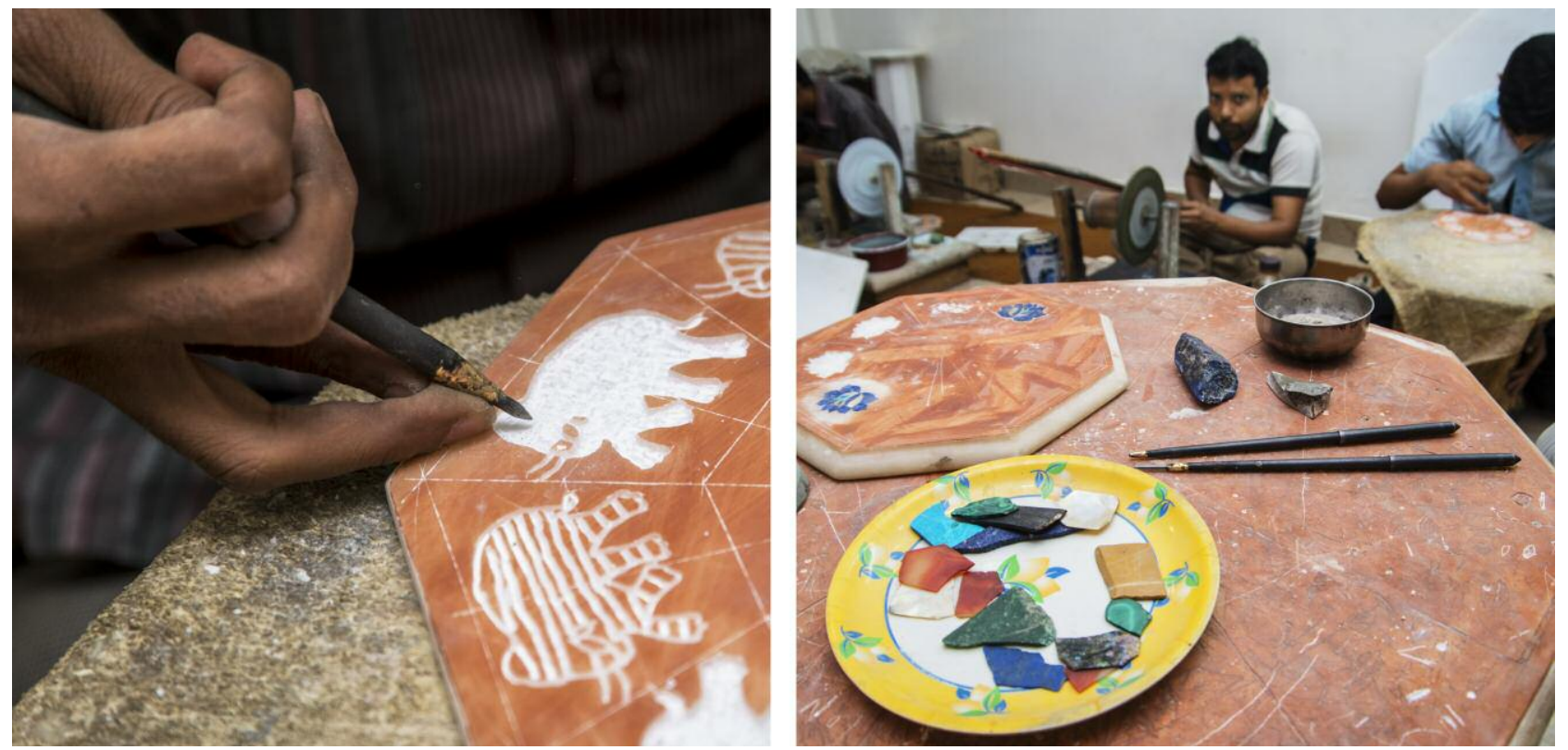


\section{Box A: History of Pietra Dura}

The Mughals were very interested in European art. European paintings and prints were the subject of exhibitions and many discussions (Koch, 2001). One style of stone inlay emerged in ancient Greece as early as the fifth century BCE (Dunbabin, 2006). This evolved into the use of small slices of opaque and semitransparent gems such as carnelian and other agates, lapis lazuli, and jasper that were cut and set into a base material such as marble to create the effect of a painting. Florence became a center for this style of art, and in 1588 the Grand Duke Ferdinand established the first state factory in the Uffizi Galleries, the Opificio delle Pietre Dure, which operated well into the nineteenth century. The facility is now a museum (Giusti, 2006).

Nature themes were often the focus of the pietra dura style. Flowers, landscapes, and birds and other animals were executed with such an exuberance of colors and style that they immediately became popular throughout Europe. Large vases, ewers, and bowls were later fashioned with pietra dura and set in elaborate mounts of gold and enamel. Even statuettes and life-size busts were made of inlaid marble, but these were very rare and reserved only for royalty.
Similar workshops were established throughout Europe. In Prague, Rudolf II employed the Miseroni family from Milan and the Castruccis from Florence to create new and elaborate forms of pietra dura for the palaces of the Habsburg rulers. In France, pietra dura was produced in Louis XIV's ateliers and incorporated in ornamented furniture. There was a reaction against this style during the Rococo period, which was marked by scrolling curved forms and gilded opulence. Many pieces were dismantled, only to enjoy a triumphant revival in furniture of the Louis XVI period. Workshops flourished in Germany, Italy, and Spain, where Carlos of Bourbon's artisans specialized in superb consoles and inlays of landscapes, figures, and trompe l'oeil. A seventeenth-century cabinet designed by Robert Adam and housed in the Victoria and Albert Museum is inset with pietra dura panels signed by Baccio Cappelli, one of the Uffizi workmen.

During the Victorian era, which spanned most of the nineteenth century, pietra dura was used for small pieces such as desk blotters, inkstands, postal scales, and lamp bases. These accessories are not as scarce or costly as the furniture from two centuries earlier, and as a consequence they can be unearthed at antique shows and shops.
India to work on the Taj Mahal. The Mughals had received gifts from Italy of decorative objects with inlay and had acquired an appreciation for the art.
History of the Families that Performed the Inlay. The pietra dura inlay technique was handed down from generation to generation, beginning with fam-

Figure 19. Slivers of carnelian, malachite, turquoise, and lapis lazuli are cut and assembled for inlay in modern parchin kari decorative pieces. Photos by Robert Weldon/GIA.
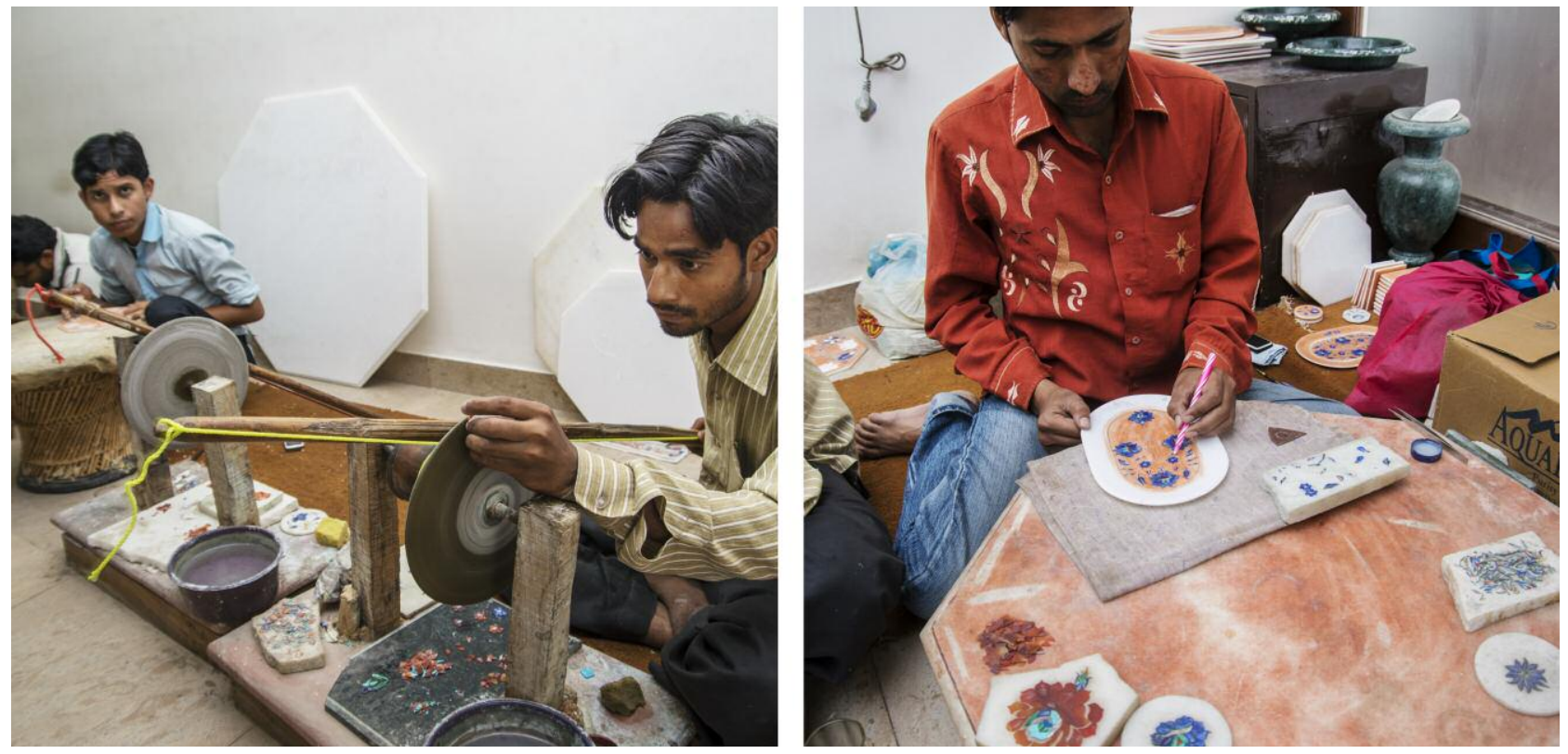


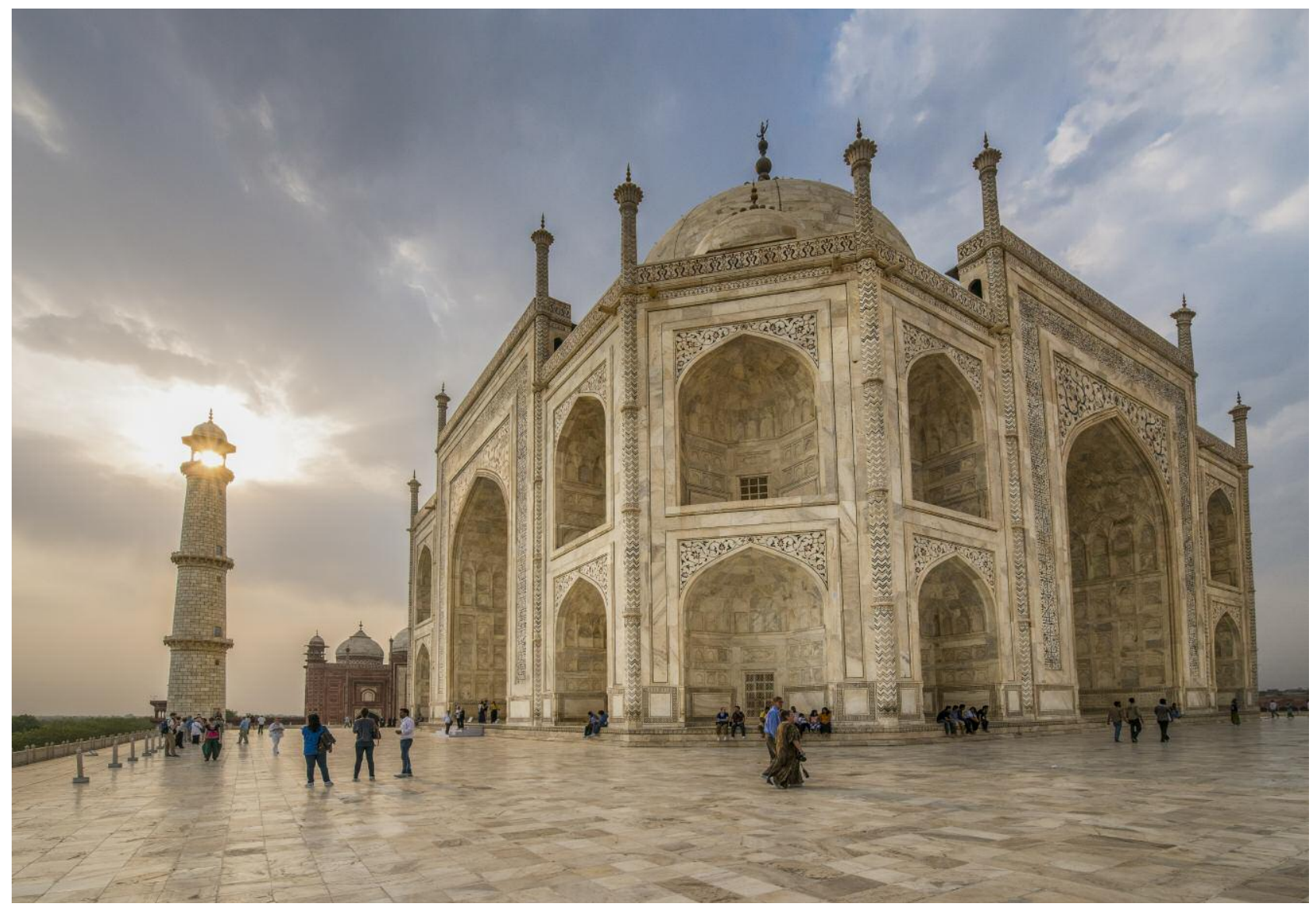

Figure 20. Minarets at the Taj Mahal frame its four corners. At sunset, sunlight peeks through the minarets, adding to their mystical enchantment. From this view, the superb inlay and craftsmanship of the mausoleum are visible. Photo by Robert Weldon/GIA.

ilies in Europe and then moving east into Russia. From there, the technique was passed from fathers to sons in northern Afghanistan. It was in Afghanistan that the art of calligraphy in stone began (Kazim, 2014).

The tradition of fine stone inlay, or parchin kari, developed independently in India and began to be incorporated into the monuments of the Mughal empire during the sixteenth century. Because of the close relationship between the development of pietra dura in Renaissance Italy and parchin kari at the Mughal court, the terms are often used interchangeably (L. Thoresen, pers. comm., 2019). Parchin kari is still used in India today on tables, plaques, tiles, and other decorative items (figure 20). Records indicate that the parchin kari craftsmen were mostly from Kannauj and were not Muslim but Hindus (Havell, 2003). A lesser-known literary work, The History of the Taj and the Buildings in Its Vicinity by Moin-Ud-Din (1905), lists the names of men who worked on various aspects of the Taj Mahal.
Symbolic Significance of the Designs. The floral pattern inlaid in the marble throughout the Taj Mahal is not random. Persian culture strongly influenced the Mughals. Floral imagery abounds in Persian poetry (Wescoat et al., 1996), which describes flowers as "springing forth from the waters of Paradise" (Janin, 2004), and this symbolism was no doubt the intention for Mumtaz's final resting place ("Taj Mahal," 2007). In the case of the Taj Mahal's floral motif, the choice of red and yellow as prevailing colors was most likely deliberate. Red blossoms represent death and blood in Persian poetry, while yellow denotes rebirth and dispels grief. Although some of the flowers of the Taj Mahal are creations sprung from the minds of the craftsmen, others are depictions of real flowers such as lilies (similar to martagon lilies), tulips, poppy blossoms, buds, and calyxes (Koch, 2006) (figure 21).

The red flowers are a symbol of sorrow, anguish, and death-poppies specifically are associated with the dead in Islamic thought (Koch, 2006). The Persian poet Hafiz claimed in the fourteenth century that 


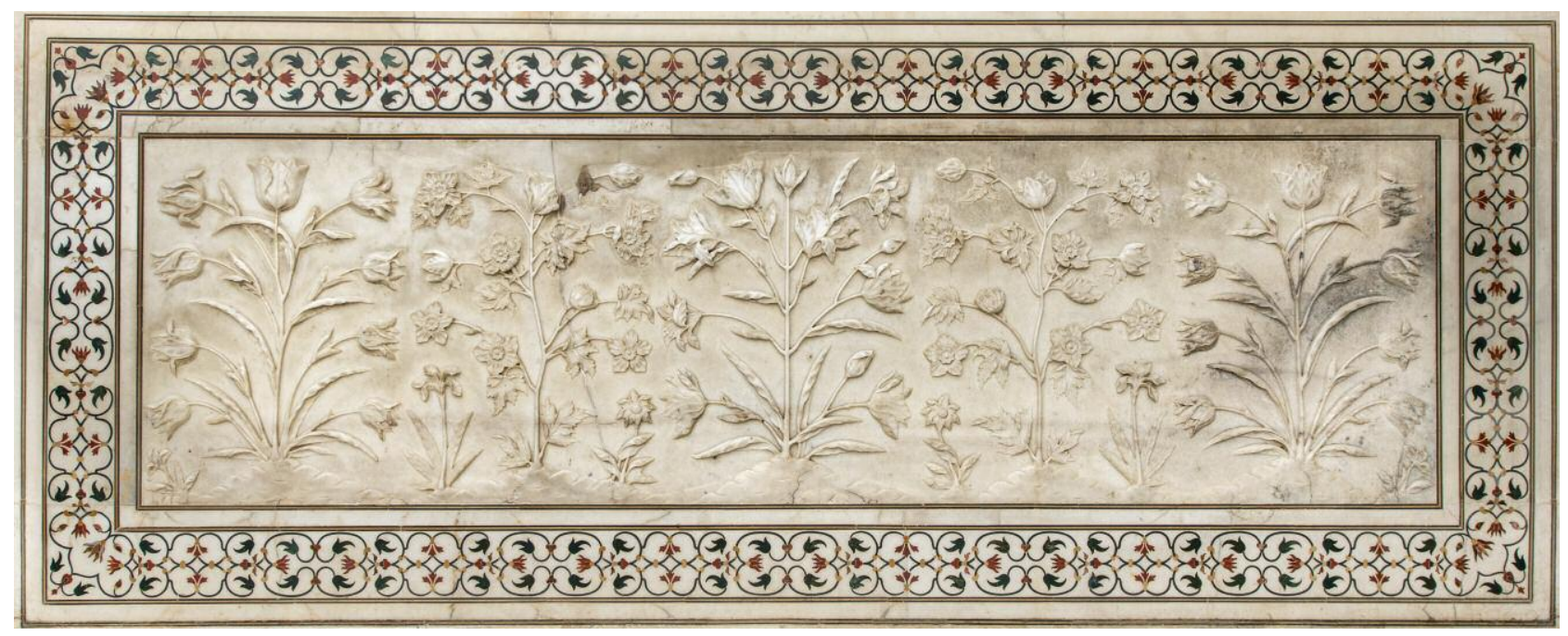

Figure 21. This large panel of carved marble with floral motifs at the Taj Mahal contains a border of parchin kari. Photo by Robert Weldon/GIA.

tulips are tokens of great love (Hafiz, 1905; Connolly, 2004). Poppies and red flowers similar to lilies embellish the upper cenotaphs of Mumtaz Mahal and Shah Jahan. Their graceful leaves and blooms rain down in sorrow, and the blood red stands in contrast against the stark white of the marble.

Both cenotaphs feature inscriptions of black onyx inlay. The Arabic inscription that runs around the sides and along the top of Mumtaz Mahal's cenotaph are verses from the Koran, meant to put her soul at ease. The cenotaph of Shah Jahan features an ornate epitaph in Nasta'līq calligraphy (containing a pronounced rounded script) that reads:

This is the sacred grave of His Most Exalted Majesty, Dweller in Paradise, Second Lord of the Auspicious Conjunction, Shah Jahan, Padshah; may it ever be fragrant! The year 1076 [AD 1666] (Koch, 2006).

While the cenotaphs on the main level are meant for public view, and are aligned to the north, the actual tombs of Shah Jahan and Mumtaz lie in a chamber just below, facing west, toward Mecca. In keeping with Islamic tradition, these actual tombs are much simpler in design.

Islamic Inscriptions. Words from the Koran are similarly inlaid throughout the complex using black onyx. The inscription process itself was ambitious, as more than two dozen Koranic quotations are displayed on the Great Gate, mausoleum, and mosque. In a sense, this work is even more intricate because the onyx had to be carved to fit the script of the letters. The passage from the Koran on the Great Gate calls the charitable and the faithful to enter Paradise (figure 22). The artist responsible for these inscriptions, Abd al-Haqq Shirazi, is the only artist whose

Figure 22. The eastern facade of the Taj Mahal is framed by parchin kari and an inscription from the Koran. Photo by Robert Weldon/GIA.

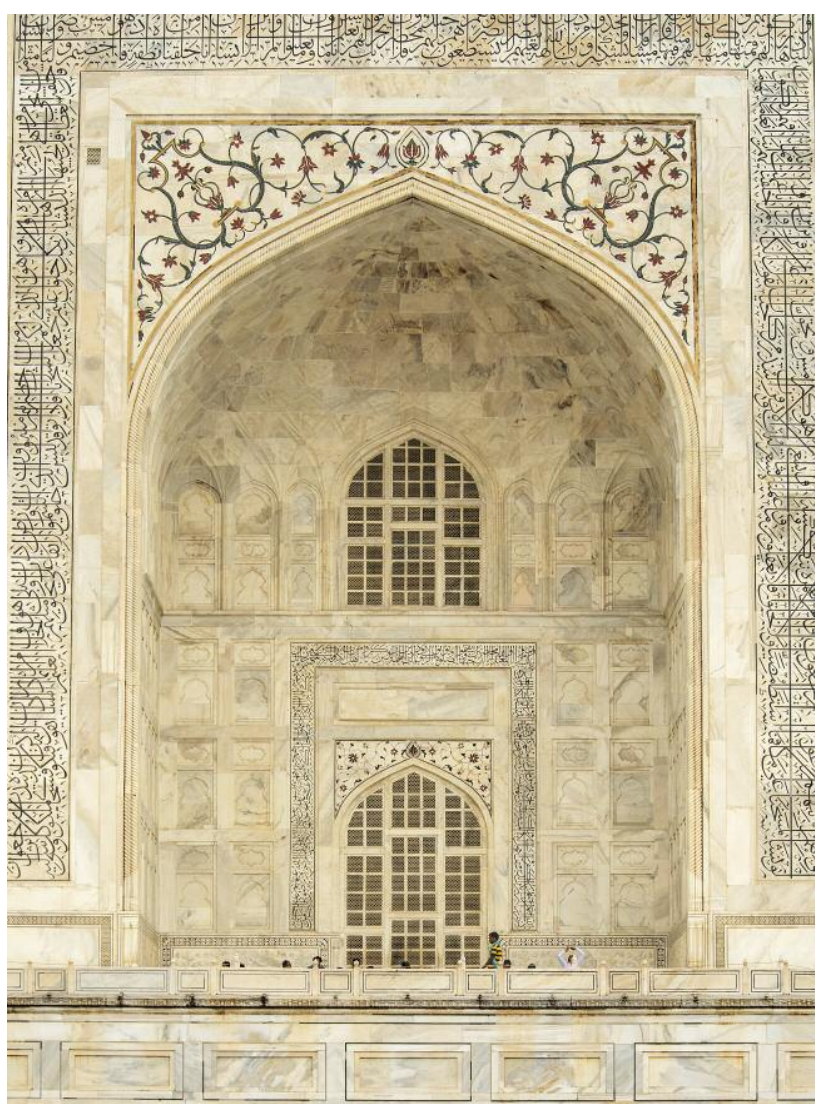


name was allowed on the Taj Mahal for posterity. This further demonstrated Shah Jahan's high regard for the inscriptions and the artist. As Al-Haqq Shirazi had designed the inscriptions for the tomb of Akbar, Shah Jahan's grandfather, he was the logical choice (Begley, 1978/1979). One of the three dated epigraphs inscribed at the Taj Mahal reads "Finished with His help" and was written by Amanat Khan al-Sjorazo in the year corresponding to the twelfth year of Shah Jahan's reign, somewhere between October 1638 and April 1639. The larger words are in Arabic and the smaller ones in Persian (Begley, 1978/1979).

The Taj Mahal Today and Its Conservation. On April 11,2018 , severe storm winds caused two minarets at the Taj Mahal to collapse. Fortunately, the taller ones remained standing. While one of the destroyed minarets was located at the southern gate, the other was at the royal gate, where one gets a first glimpse of the Taj Mahal. This world wonder also faces deterioration from exposure to air pollution and wear from its eight million visitors every year. The result is a general yellowing of the buildings. As the custodians of this monument, the Archaeological Survey of India reported in January 2018 that the Taj Mahal was in danger of losing its attractive marble gloss due to air pollution in Agra ("India Taj Mahal minarets damaged...," 2018).

For a time up until the restoration by British Viceroy Lord Curzon was completed in 1908, security was not stringent, so some of the stones in the pietra dura as well as other decor were stolen ("Theft in Taj Mahal myth," n.d.). The Archaeological Survey of India stated that it would take until 2018 to clean the buildings, replace the missing stones, and take protective measures to minimize further damage by visitors (Devi, 2015). Most of the work has been accomplished, though some questions remain as to the safest method of cleaning the Taj Mahal's main dome, which was scheduled for late 2019.

To remove the yellow stains, a clay pack known as multani mitti (or fuller's earth), known since the late 1800s, was applied for decades with positive results on the building exteriors. This facial treatment consisting of lime, cereal, soil, and milk was slathered onto the buildings, left to sit for 24 hours, and then washed with warm water ("Multani mitti is being used...," 2002) (figure 23).

Governmental protection began in 1996, when the Supreme Court of India enacted the Taj Trapezium Zone, a 10,400 square $\mathrm{km}$ area surrounding the Taj Mahal complex. This trapezoid-shaped zone,

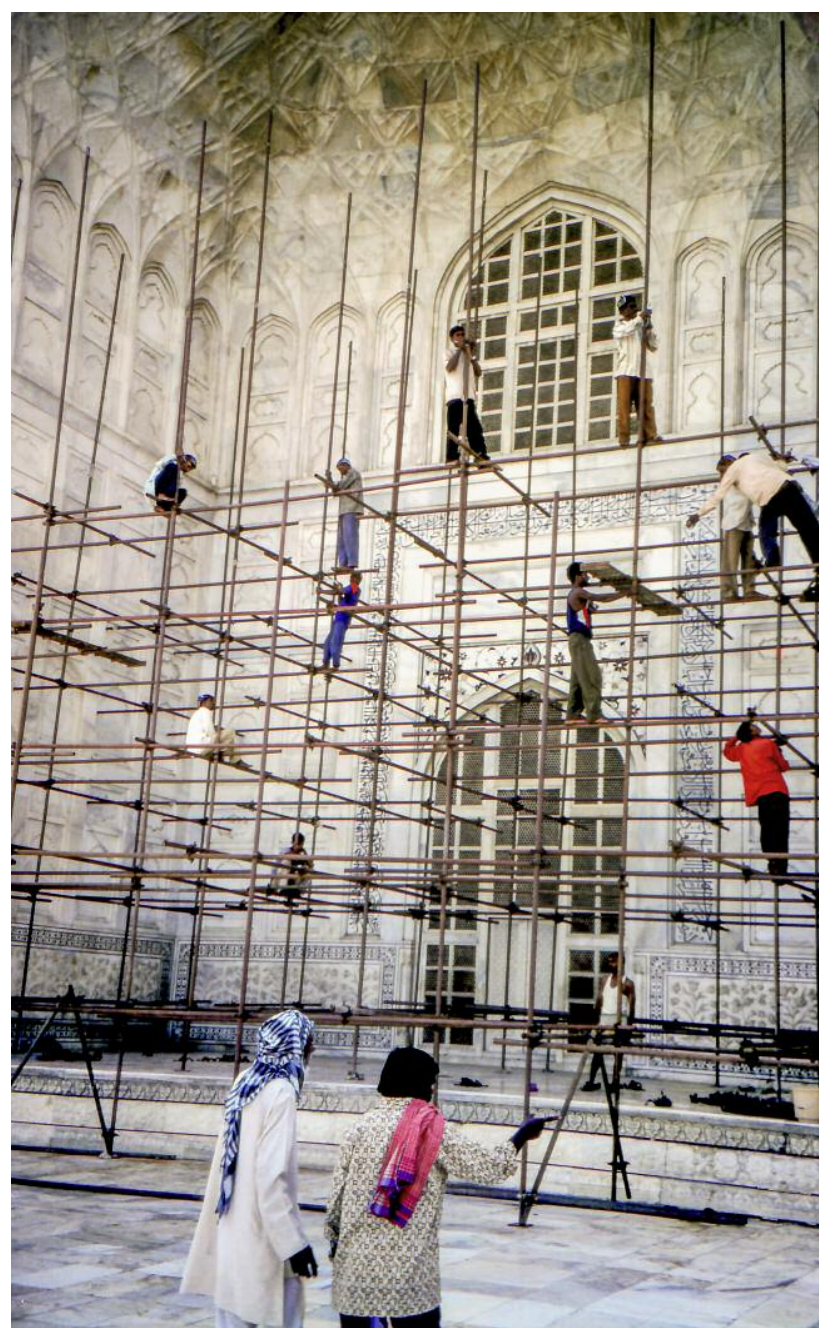

Figure 23. Scaffolding was erected for chemical cleaning of the northern pishtaq of the mausoleum in September 2002. Reproduced with permission of Ebba Koch, 2006.

meant to protect the Taj from environmental pollution damage, bans the burning of coal within the area. It also requires some industries to switch to natural gas or even relocate outside of the zone ("Why is the Taj...," 2008). Another measure to control pollution has been to ban the burning of cow dung, used for kindling in wood fires, within Agra ("Fuel guzzling vehicles...," 2015). Fuel-powered vehicles are banned within 500 meters of the Taj Mahal (Lusted, 2013). Visitors arrive by foot or electric shuttle. Upon arrival, they can either go barefoot or wear covers over their shoes. Most recently, it was reported that the Archaeological Survey of India was considering the use of spectrography to measure incremental differences in the Taj Mahal's exterior color. The first step was cleaning the surface of the marble using 
multani mitti, as discussed earlier. From now on, the changes will be recorded over time and reported to the Supreme Court of India (Qureshi, 2019).

Some of the restoration planning and execution is culturally fraught. But despite cultural differences and debate over financial allocations, the Supreme Court instructed the Indian government to take immediate action: "Even if you have the expertise, you are not utilizing it. Or perhaps you don't care. We need to save it," the court urged (Meixler, 2018).

\section{CONCLUSIONS}

The Taj Mahal is a monument to an everlasting love. The indefatigable Mughal emperor Shah Jahan had it built 366 years ago for his wife Mumtaz's final resting place. Much like his father, Jahangir, Shah Jahan was one of the most prolific gem collectors and connoisseurs of his day (figure 24). The sources of the 40 or more gem materials (Dayalan, 2006) that are incorporated into the Taj Mahal's facade tell a compelling story of global trade and commerce. This culturally rich era brought about an exchange of gems and knowledge, fostering craftsmanship and cultural adaptations from Europe and Asia. Raw materials were also the catalysts for attracting the world's most talented lapidaries, architects, stonemasons, and workers, who made possible an unsurpassed creation.

India itself has been a major source of gems since antiquity, including its fabled diamonds from the Golconda region and agates from the Deccan Traps.

Figure 24. The finest parchin kari work was reserved for Mumtaz's cenotaph, in the interior of the mausoleum. Photo by Jean-Louis Nou, courtesy of AKG Images.

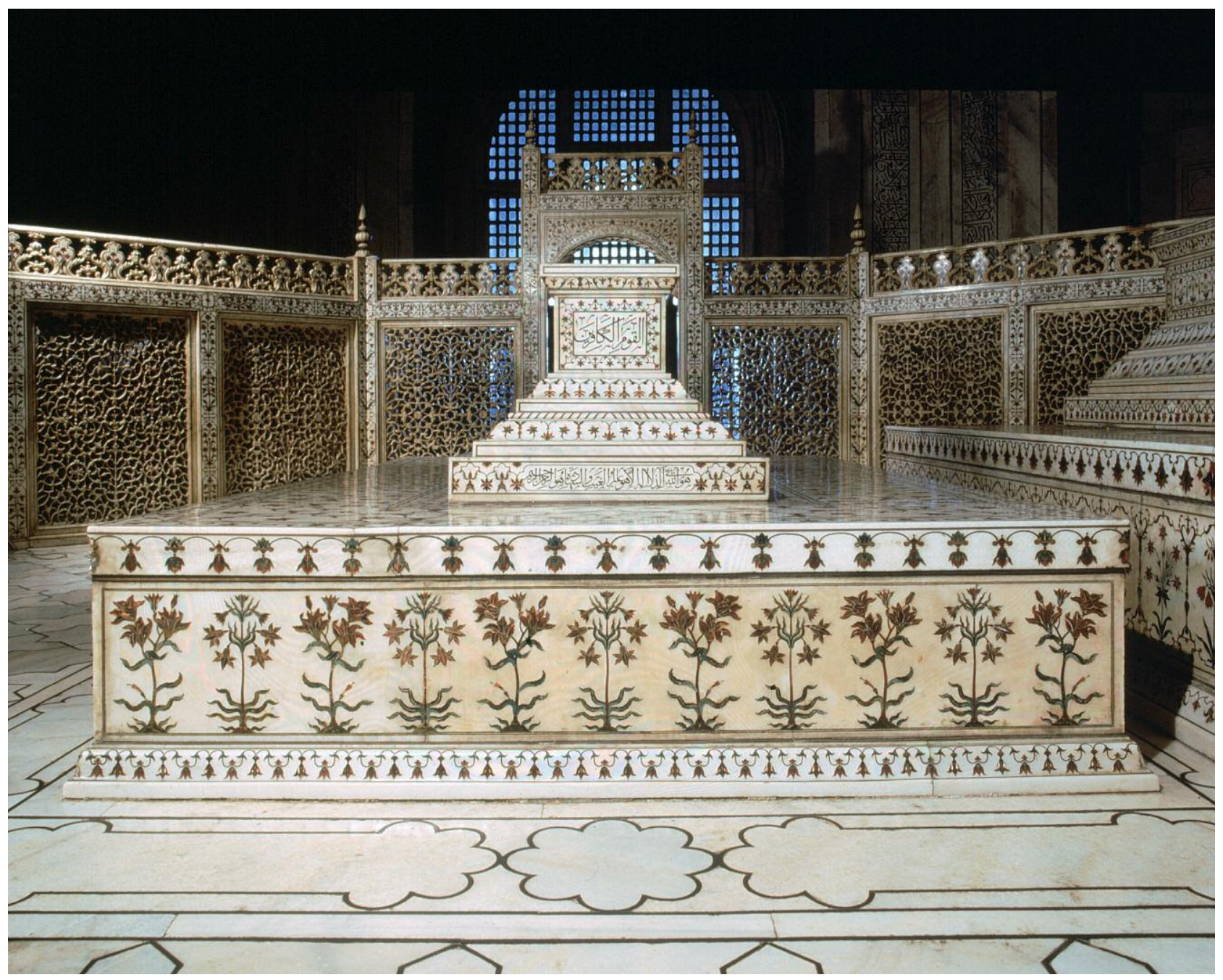




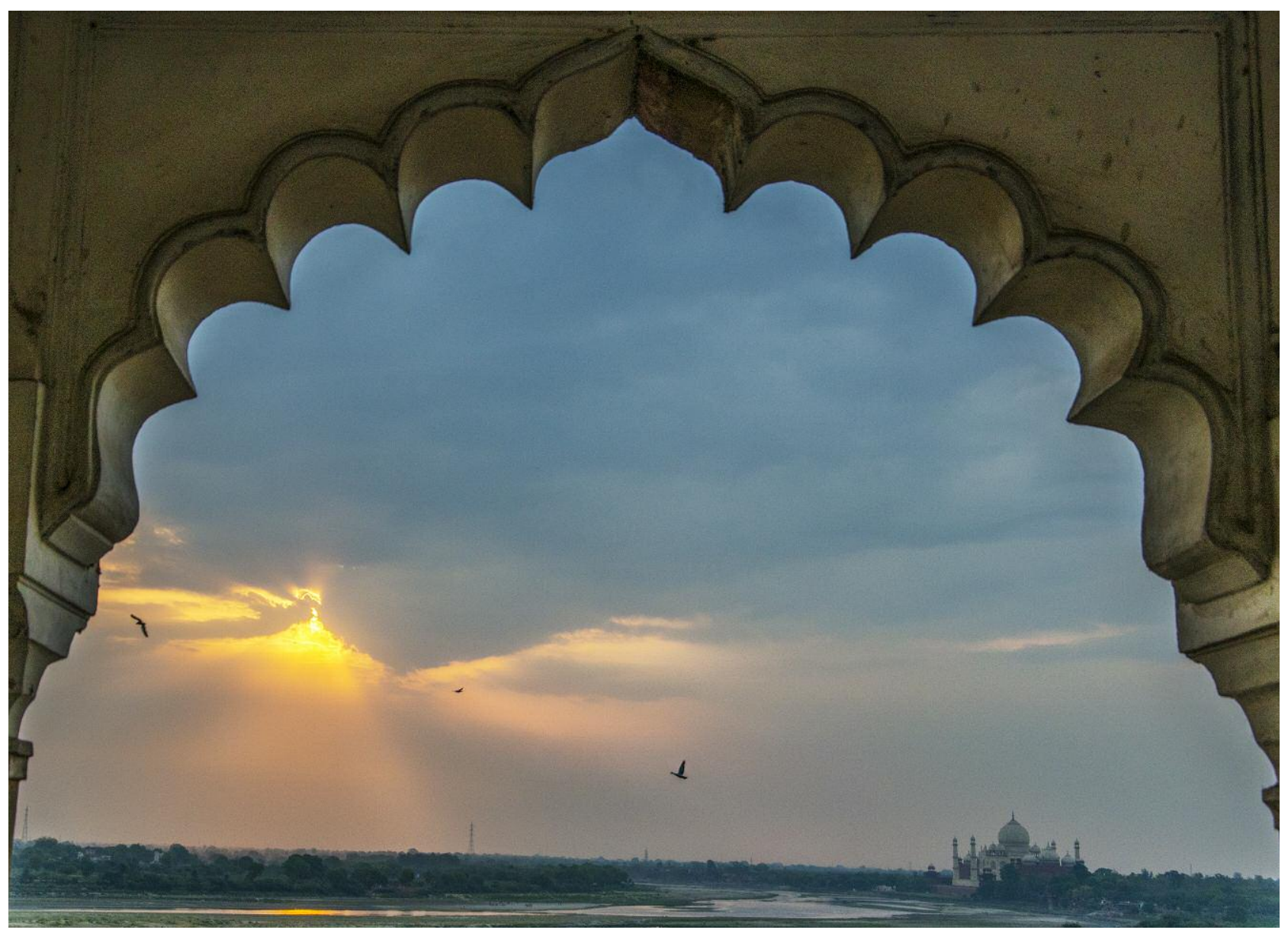

Figure 25. The Taj Mahal is visible in the distance from Agra Fort, where Shah Jahan was imprisoned by his son Aurangzeb in 1658. He would have had a futile daily view of the Taj Mahal at sunrise, positioned on the bank of the glimmering Yamuna River. Photo by Robert Weldon/GIA.

Although much of the Mughals' exquisite jewelry has been melted down to make new ornaments (Sharma and Varadarajan, 2004), we can still enjoy the beauty of the era through the artistry of the Taj
Mahal, which has stood the test of time. As millions continue to visit each year, conservation will be essential to preserve its beauty for generations to follow (figure 25).

\section{ABOUT THE AUTHORS}

Ms. Dirlam is librarian emeritus, Ms. Rogers is a research librarian, and Mr. Weldon is director, of GIA's Richard T. Liddicoat Gemological Library and Information Center in Carlsbad, California.

\section{ACKNOWLEDGMENTS}

The authors would like to thank the following for their assistance: Tarun Adlakha, Faizah Bhatti, Si and Ann Frazier, Dr. Ebba Koch, Tsajon von Lixfeld, Lisbet Thoresen, Bhupendra Mookim, Ashoo Sinchawla, and the staff of the Richard T. Liddicoat Gemological Library and Information Center.

\section{REFERENCES}

Bala Krishnan U.R., Sushil Kumar M. (2001) Indian Jewellery: Dance of the Peacock. India Book House Ltd., Mumbai, pp. 2053, 110-135.

Balasubramaniam R. (2009) New insights on artisans of Taj. Indian Journal of History of Science, Vol. 44, No. 4, pp. 521-550.
Ball S.H. (1931) Historical notes on gem mining. Economic Geology, Vol. 26, No. 7, pp. 681-738.

Ball V. (1977a) Travels in India by Jean-Baptiste Tavernier, Vol. 1 2nd ed. Oriental Books Reprint Corporation, New Delhi, 335 pp. 
Ball V. (1977b) Travels in India by Tean-Baptiste Tavernier, Vol. 2, 2nd ed. Oriental Books Reprint Corporation, New Delhi, 399 pp.

Begley W. (1978/1979) Amanat Khan and the calligraphy on the Taj Mahal. Kunst des Orients, Vol. 12, No. 1/2, pp. 5-60. http://www.jstor.org/stable/20752477

Begley W. (1979) The myth of the Taj Mahal and a new theory of its symbolic meaning. The Art Bulletin, Vol. 61, No. 1, pp. 7-37. http://www.collegeart.org/pdf/artbulletin/Art\%20Bulletin $\% 20$ Vol\% 2061\%20No\%201\%20Begley.pdf

Brill E. (1993) E.J. Brill's First Encyclopaedia of Islam, 1913-1936. Brill Academic Publishing, Boston, pp. 886-887.

Budge E.A.W. (1968) Amulets and Talismans. University Books, New Hyde Park, p. 311.

Budge E.A.W. (2011) Amulets and Superstitions. Dover Publications, New York, p. 317.

Connolly S. (2004) The Secret Language of Flowers. Rizzoli International Publications, New York, p. 86.

Dayalan D. (2006) Use of Remote Sensing and GIS in the Management and Conservation of Heritage Properties at Agra. Archaeological Survey of India, New Delhi.

Delmerick J.G. (1883) On a silver coin of Dáwar Bakhsh. In Proceedings of the Asiatic Society of Bengal: 1883-34. Asiatic Society, Calcutta, p. 60.

Devi A. (2015) ASI backtracks, says Taj restoration will take only 3 yrs. The Times of India, Sept. 30, http://timesofindia.indiatimes.com/city/agra/ASI-backtracks-says-Taj-restoration-willtake-only-3-yrs/articleshow/49180538.cms

Dunbabin K. (2006) Mosaics of the Greek and Roman World. Cambridge University Press, Cambridge, p. 5.

Frankopan P. (2017) The Silk Roads. Penguin Random House, New York, p. 231

Fuel guzzling vehicles to go off Taj Trapezium Zone (2015) The Hindu, Jan. 31, http://www.thehindu.com/todays-paper/tp-inschool/fuel-guzzling-vehicles-to-go-off-taj-trapezium-zone/article6840248.ece

Giusti A. (2006) Pietre Dure: The Art of Semiprecious Stonework. Getty Publications, Los Angeles, p. 47

Hafiz (1905) Odes from the Divan of Hafiz. Duckworth, London. p. 169.

Haidar N., Stewart C.A. (2014) Treasures from India: Jewels from the Al-Thani Collection. Yale University Press, New York, p. 23.

Havell E. (2003) Handbook to Agra and the Taj-Sikandra, Fatehpur - Sikri. Asian Education Services, New Delhi, p. 141.

Horowitz W. (1998) Mesopotamian Cosmic Geography. Eisenbrauns, Warsaw, p. 14

India Taj Mahal minarets damaged in storm (2018) BBC News, April 12, http://www.bbc.com/news/world-asia-india-43735757

Jaffer A., Ed. (2013) Beyond Extravagance: A Royal Collection of Gems and Jewels. Assouline Publishing, New York. p. 26-56.

Janin H. (2004) The Pursuit of Learning in the Islamic World, 6102003. McFarland \& Company, Jefferson, North Carolina, p. 125.

Jones W. (1968) History and Mystery of Precious Stones. Singing Tree Press, Detroit, p. 31.

Kazim S. (2014) Pietra dura-an art form passed down through centuries. Dawn, Apr. 30. http://www.dawn.com/news/1103225

Koch E. (2001) Mughal Art and Imperial Ideology. Oxford University Press, New Delhi, p. 63.

Koch E. (2006) The Complete Taj Mahal. Thames \& Hudson, Ltd., London.

Kunz G.F. (1938) The Curious Lore of Precious Stones. Halcyon House, New York.

Lane K. (2010) Colour of Paradise: The Emerald in the Age of Gunpowder Empires. Yale University Press, New Haven, Connecticut, $280 \mathrm{pp}$

Latif M. (1982) Mughal Jewels. F. Poot, Brussels, p. 21.
Lusted M.A. (2013) Taj Mahal: how long will it last? Faces, Vol 30, No. 3, p. 24

Markel S. (2004) Non-imperial Mughal sources for jades and jade simulants in South Asia. In Jewelled Arts of Mughal India: Papers of the Conference Held Jointly by the British Museum and the Society of Jewellery Historians at The British Museum, London in 2001. Society of Jewellery Historians, London, pp. 68-75.

Meixler E. (2018) The Taj Mahal is changing color. That has India's highest court concerned. https://time.com/5262395/taj-mahalindia-change-color-supreme-court/

Melikian-Chirvani A. (2004) The jewelled objects of Hindustan. Jewellery Studies, Vol. 10, pp. 9-32.

Moin-Ud-Din M. (1905) The History of the Taj and the Buildings in Its Vicinity. Moon Press, Agra, p. 27.

Mubarak A. (1894) The Ain I Akbari. The Asiatic Society of Bengal, Calcutta, p. 315.

Multani mitti is being used to beautify Taj Mahal: Report (2002) The Times of India, December 8, http://timesofindia.indiatimes.com/topic/Multani-Mitti-Is-Being-Used-To-Beautify-TajMahal:-Report

Nath R. (1985) The Taj Mahal ↔) Its Incarnation: Original Persian Data on Its Builders, Material, Costs, Measurements, etc. The Historical Research Documentation Programme, Jaipur, p. 13

Qureshi S. (2019) ASI looking for scientific methods to protect Taj Mahal from pollution. India Today, March 11, https://www.indiatoday.in/india/story/asi-looking-for-scientific-methods-toprotect-taj-mahal-from-pollution-1474984-2019-03-11

Sarkar J. (1920) Studies in Mughal India. Longmans, London.

Sharma R.D., Varadarajan M. (2004) Handcrafted Indian Enamel Jewellery. Roli Books, New Delhi, 144 pp.

Tagore S. (1881) Mani-Málá, or a Treatise on Gems. I.C. Bose \& Company, Calcutta.

The Taj Mahal (n.d.) http://thetajmahal.co.in/art-and-architecture/engineering-team-taj-and-costs/

Taj Mahal (2007) Lost Worlds. The History Channel, aired November 28.

Tavernier J.-B. (1678) The Six Voyages of John Baptista Tavernier, a Noble Man of France Now Living, Through Turky [sic] into Persia and the East-Indies, Finished in the Year 1670. Printed for R.L. and M.P., London, p. 58-83.

Theft in Taj Mahal myth (n.d.) Retrieved from https://www.tajmahal.org.uk/legends/theft-in-taj.html

Thomas W., Pavitt K. (1993) The Book of Talismans: Amulets and Zodiacal Gems. Bracken Books, London, p. 222.

Thoresen L. (2017) Archaeogemmology and ancient literary sources on gems and their origins. In A. Hilgner et al., Eds., Gemstones in the First Millennium AD: Mines, Trade, Workshops and Symbolism: International Conference, October 2022, 2015. Verlag des Römisch-Germanischen Zentralmuseums, Mainz, Germany, pp. 155-217.

Vassallo e Silva N., Flores J., Eds. (2004) Goa and the Great Mughal. Scala Publishers Ltd, London, pp. 240

Voysey H. (1825) On the building stones and mosaic of Akberabad or Agra. Asiatic Researches, or Transactions of the Society, Vol. 15. Asiatic Society, Calcutta, pp. 429-435.

Weldon R., Ortiz J.G., Ottaway T. (2016) In Rainier's footsteps: Journey to the Chivor emerald mine. $G \uplus G$, Vol. 52, No. 2, pp 168-187, http://dx.doi.org/10.5741/GEMS.52.2.168

Wescoat J., Wolschke-Bulmahn J., Oaks D. (1996) Mughal Gardens: Sources, Places, Representations, and Prospects. Dumbarton Oaks Research Library and Collection, Washington D.C., p. 233.

Why is the Taj Trapezium Zone and why is it called so? (2008) The Times of India, May 4, http://timesofindia.indiatimes.com/ home/sunday-times/Why-is-the-Taj-Trapezium-Zone-andwhy-is-it-called-so/articleshow/3008537.cms 